\title{
The association between aggressive behaviors and academic self-esteem of preschool children
}

\author{
Chrische' Marie Walker \\ West Virginia University
}

Follow this and additional works at: https://researchrepository.wvu.edu/etd

\section{Recommended Citation}

Walker, Chrische' Marie, "The association between aggressive behaviors and academic self-esteem of preschool children" (2006). Graduate Theses, Dissertations, and Problem Reports. 2484.

https://researchrepository.wvu.edu/etd/2484

This Thesis is protected by copyright and/or related rights. It has been brought to you by the The Research Repository @ WVU with permission from the rights-holder(s). You are free to use this Thesis in any way that is permitted by the copyright and related rights legislation that applies to your use. For other uses you must obtain permission from the rights-holder(s) directly, unless additional rights are indicated by a Creative Commons license in the record and/ or on the work itself. This Thesis has been accepted for inclusion in WVU Graduate Theses, Dissertations, and Problem Reports collection by an authorized administrator of The Research Repository @ WVU. For more information, please contact researchrepository@mail.wvu.edu. 
The Association between Aggressive Behaviors and Academic Self-Esteem of Preschool Children

\author{
Chrische' Marie Walker
}

Submitted to the College of Human Resources and Education at West Virginia University in Partial Fulfillment of the Requirements

for the degree of

\author{
Master of Arts \\ in
}

Educational Psychology

Bobbie G. Warash, Ed.D., Chair

Carol A. Markstrom, Ph.D.

Erron L. Huey, Ph.D.

Department of Technology, Learning and Culture

Morgantown, West Virginia

2006 


\author{
ABSTRACT \\ The Association between Aggressive Behaviors \\ and \\ Academic Self-Esteem of Preschool Children
}

\begin{abstract}
Chrische' Marie Walker
The intent of this study was to investigate the association between preschooler's aggressiveness behavior and their academic self-esteem in the classrooms. The participants in this study consisted of 63 preschoolers who attended the West Virginia University Laboratory Nursery School or the Pierpont Christian Preschool during the school year of 2005-2006. The preschoolers were rated by their teachers at each school on their student initiative, social attraction, success/failure, social attraction, self-confidence on the Behavioral Academic Self-Esteem Scale (BASE) and their aggressiveness with peers on the Child Behavior Scale (CBS).

Results of the study indicated that the preschooler's academic self-esteem and aggressive behaviors were associated with each other. Teachers rated the preschoolers differently due to personality and or differences in perceptions. There was a significant difference in the scores of each child in each facility.
\end{abstract}


Dedicated to:

My Parents

Frank and Deborah Walker 


\section{ACKNOWLEDGEMENTS}

I would like to acknowledge my sincere appreciation to the people who made it possible for the completion of this project. Your contributions were greatly appreciated. To my graduate adviser and committee chairperson, Dr. Bobbie Warash, thank you for being so patient and helping me throughout all revisions, for helping me complete forms for the project, for supporting me throughout the project, for your guidance, and for your kindness and the dedication of your time. It was indeed greatly appreciated. To my committee members, Dr. Erron Huey and Dr. Carol Markstrom, Dr. Huey, I thank you for guiding me in the right direction towards this project. Your kindness and your dedication were greatly appreciated. Thank you for your words of encouragement that made me believe that this can happen. Thank you for your time in analyzing my data and also your extra time throughout the summer months. Dr. Markstrom, I thank you for your words of encouragement and everything that you did to make this project possible. Thank you for checking in on me through e-mails to see how the project was coming along. I really appreciated the extended communication from you. Thank you so much committee members, without you this project would not have been possible.

I would like to sincerely thank the West Virginia University Laboratory Nursery School and the Pierpont Christian Preschool for allowing me to conduct my research at your facilities. I would personally like to thank the teachers who administered the Child Behavior Scale (CBS) and the Behavioral Academic Self-Esteem Scale (BASE). Your help was greatly appreciated. 
I would like to thank my family for their guidance, support, and encouraging words. To Mom and Dad, I thank you for all of your love and support. Mommy, I will always remember your words, "Chrische', just take your time and pray about it." Daddy, I will always remember your words, "Chrische', "JUST DO IT." Your words of encouragement gave me strength to complete this lengthy project. Thank you sisters and brothers, Christal, Shani, Brandon (Mikah \& Braylin), and Frankie (Jennifer \& Hannah) for being so supportive. To my Aunt Sheila and Iman, thank you for your support and putting up with me through the last and final stages of this project. Thank you ALL FAMILY for sharing this gift with me of an accomplishment and a contribution to the Walker and Moore Family.

I would like to thank my friend and my colleague, Rebecca Summers. We finally did it!! This is an accomplishment for the both us. I thank you for being by my side throughout this entire project. It was great to experience graduate school with you and completing this thesis together. It was a challenge for the both of us and we made it through. I just wanted to say thank you for all your help and encouraging words. I wish you success in the future!! Let's Go Mountaineers!!

This project has indeed been a major part of my educational career. It has showed me that completing a thesis is possible with the encouragement and support from my professors, family, and friends. It is indeed a great accomplishment for me. With this thesis, I hope that people will understand and learn a little about preschoolers and their behaviors. 
Table of Contents

Page

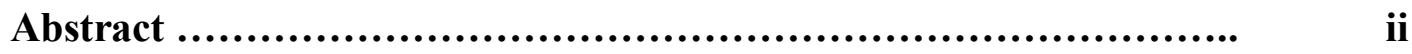

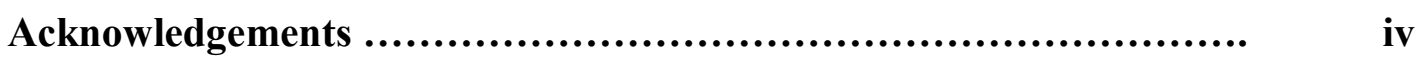

Chapter

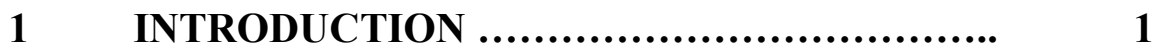

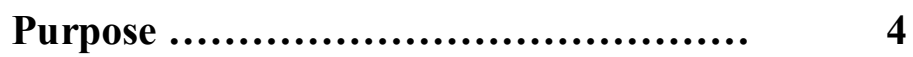

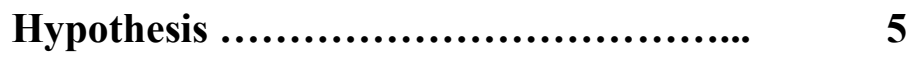

2 LITERATURE REVIEW ........................... 6

Self-Esteem \& Academic Self-Esteem...... 6

Aggression ................................ 10

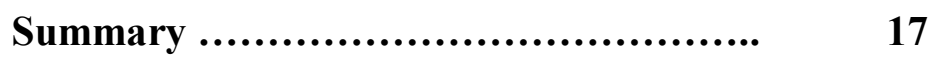

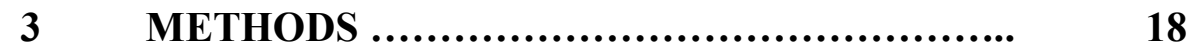

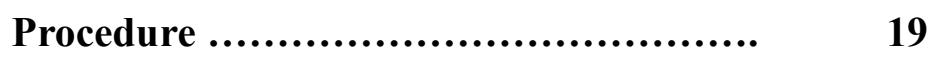

Child Behavior Scale (CBS)........ 20

Behavioral Academic Self-Esteem.. $\quad 21$

(BASE)Rating Scale

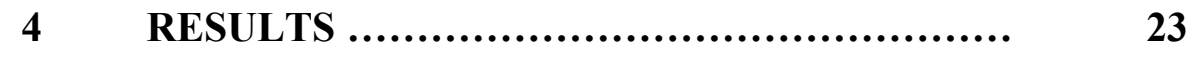

Statistical Analysis ...................... $\quad 23$

Table 1: General Description of the Sample $\quad 27$

Table 2: Central Tendencies and Descriptives 28 
Table 3: ANOVA Comparisons................... 29

Table 4: Tukey's HSD Comparisons.......... 30

Table 5: Bivariate Correlations.............. 31

Table 6: Hierarchal Multiple Regressions..... 32

Chapter

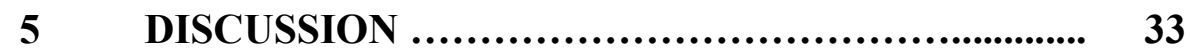

Limitations of the Study ...................... 35

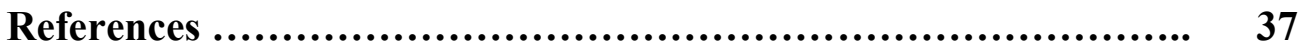

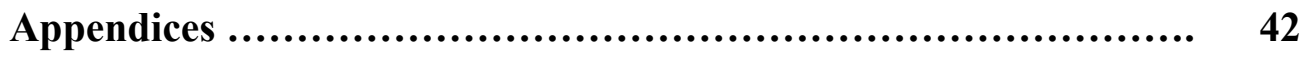

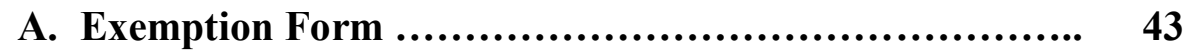

B. IRB Approval Form.................................... 47

C. Cover Letters to Teachers................................ 49

D. Permission Letters ........................................ 51

E. Request and Approval Letters for (CBS) ............... 54

F. Child Behavior Scale (CBS) ......................... 57

G. Behavioral Academic Self-Esteem Scale (BASE) ......... 60

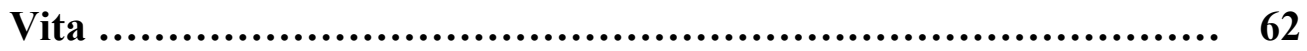




\section{Chapter One}

Introduction

During the preschool years children are expected to adequately communicate, refine motor coordination, and successfully respond to the demands of the preschool setting both in terms of achievement and behavior (Kakouros, Maniadaki, \& Karaba, 2005). One disturbing behavior that can emerge in preschool is aggression. Aggression has been recognized as a significant behavior in preschools.

Therefore, by definition, aggressive children display many behaviors that are of discomfort to others. These behaviors include fighting, bullying, kicking, biting, hitting, teasing, threatening, and arguing. Aggression has also been viewed as a personality trait, a biological process, a stereotyped reflex, a learned habit, an instinct, and a class of observable physical and verbal responses (Parke \& Slaby, 1983). Aggression can also be defined in terms of outcomes, thereby focusing attention on the harm or injuries associated with aggression. Walters, Pearce, and Dahms (1957) defines aggressive behavior as an actual attack or threatened attack upon another person, whether it is by gesture, hostile or provocative language directed toward another child or adult. Although aggression has many definitions, it has been observed as a distinct behavior in preschooler's today.

Childhood aggression can cause difficulties in a classroom setting and is of concern to both parents and teachers. Parent-child relationships, teacher-child relationships, and relationships with peers influence a child's behavior which includes aggressive behaviors (Giles \& Heyman, 2005). Parental styles and teacher interactions have an effect on the patterns of the aggressive preschool child (Maselli \& Veaco, 1984). 
Children with aggressive behaviors usually have less close relationships and more conflictual teacher-child relationships than non-aggressive children (Ladd \& Burgess, 1999). Ladd, Price, and Hart (1990) stated that the context of the children's interactions may play an important role in both the development and the modification of their peer status. Therefore, it is important to consider teacher -child and peer interactions when looking at an aggressive child.

There are many theories of aggression using an ethological approach. One of the best-known ethological treatments of aggression has been offered by Konrad Lorenz, Nobel Prize winner and author of On Aggression (Parke \& Slaby, 1983). He views aggression as a system which is generated by energy within an individual person. A dominance concept has been viewed to recognize a way of understanding children's aggression. There are a series of studies which discuss peer influences on aggression and illustrated how ethological theory can lead to valuable insights into the role of group structure in mediating control of aggressive exchanges among preschool children. As early as preschool, aggressive behavior is highly salient to peers. More importantly, aggressive behavior styles are predictive of peer rejection during the preschool years (Ladd, Price, \& Hart, 1990).

Social Learning Theory, based on Albert Bandura's ideas, refined conceptualizations of observational learning and emphasizes the possible influences of modeling in relation to behaviors. Bandura believed that the socialization of aggression, as well as other behavior, is partly a matter of operant conditioning (Crain, 2005). Parke and Slaby (1983) interpreted Bandura by suggesting that there is a complete theory of aggression which explains how aggressive patterns of behavior are developed, what 
provokes people to behave aggressively and what maintains their aggressive actions. It is recognized in the social learning theory that biological structures set limits on the type of aggressive responses that can be preformed and that genetic endowment influences the rate at which learning progresses. This theory also recognizes that aggressive behavior is acquired by the imitation of models such as parents and peers, as well as models from television and other media. There are several ways in which self-generated consequences that enter into self-regulation of aggressive behavior can be distinguished. Parke and Slaby (1983) stated that individuals who have adopted a self-reinforcement system in which aggressive behavior is a source of self-esteem and pride act aggressively to experience the self-satisfaction that is associated with acting aggressively.

With academic self-esteem not being widely observed, multiple types of selfevaluations of self-esteem will be introduced. Self-esteem consist of: (a) the discrepancy between one's real and one's ideal self-esteem; (b) the distinction between self-esteem and self-confidence, and the effect of importance of success on self-esteem; (c) the question of whether self-esteem is more appropriately considered to be a global construct or a more differentiated aggregate of self-evaluations; (d) and the degree to which selfesteem represents a hierarchical organization of the dimensions of self-evaluation (Harter, 1983). In these various issues, self-esteem can be accounted for in different ways.

A part of a child's self-esteem is his/her academic self-esteem. Academic self-esteem is reflected on how a preschooler adapts to changes in their academic classroom setting. Academic self-esteem can be described as how the child views his or her own learning abilities in relation to others (Carroll, Friedrich, \& Hund, 1984). A child's academic self- 
esteem includes a child's achievement in the classroom, social acceptance, a child's self image, and self-concept. Higher academic self-esteem contributes greatly to preschooler's initiative during a period in which they master many new skills. Children with higher academic self-esteem are likely to be very active, exploratory, and persistent. They are also eager to explore and interact with their peers in the classroom. Children with lower academic self-esteem are aggressive and often engage in attention seeking behaviors (Coopersmith, 1981). They tend to be cautious and hesitant. If teachers can provide experiences to enhance self-esteem for those children lacking it, children will respond and presumably grow more positive self-feelings. By reporting that academic self-esteem in children contributes to personal satisfaction, Coopersmith (1981) believed it was an important determinant of an individual's personality. One factor that can impact the academic self-esteem is the child's classroom environment. Children experience rapid and significant development of their academic self-esteem during the early years of childhood (Warash \& Markstrom, 2001).

Therefore, the preschool years are crucial for building the foundation for later learning in school. Observing the academic self-esteem of preschool children may give researchers more information on children's behaviors in the classroom that will later benefit early childhood practices.

Purpose of the Study

The purpose of this study was to investigate preschooler's aggressive behaviors and their academic self-esteem in the preschool classroom. Aggressive behavior was measured by using Aggressive with Peers subscale of the Child Behavior Scale (CBS) (Ladd \& Profilet, 1996). Academic self-esteem was measured by using the Behavioral 
Academic Self-Esteem (BASE) (Coopersmith \& Gilberts, 1982). The prediction in this study was that aggressiveness with peers should be associated with academic self-esteem. For preschoolers, aggressiveness with peers should be associated with social attention behaviors, student initiative behaviors, success/failure behaviors, social attraction behaviors, and self-confidence of academic self-esteem. 


\section{Chapter Two}

\section{Literature Review}

The literature reviewed for this study focused on self-esteem, academic selfesteem, and aggression of preschoolers in academic settings.

\section{Self-Esteem and Academic Self-Esteem}

Academic self-esteem can be described as how the child views his or her own learning abilities in relation to other classmates (Carroll et al., 1984). Academic selfesteem reflects how a child effectively adapts to changes in their environment. It is perception of how a child sees themselves in the classroom academically. Warash and Markstrom (2001) conducted a study on academic self-esteem of three to five year olds who attended a university laboratory school. Questionnaires were completed by mothers and fathers and by the head teacher at the laboratory school. The head teacher of the laboratory school completed the Behavioral Academic Self-Esteem Rating Scale (Coopersmith \& Gilberts, 1982). It was found that girls had higher academic self-esteem when fathers were more consistent in their parenting behaviors. Detachments and temper played a major role in parental contributions to their child's academic self-esteem. The father's temper and detachment significantly positively correlated with success and failure and total academic self-esteem. In contrast, the mother's higher scores on temper and detachment were not productive for their daughter's academic self-esteem in areas of social attention, social attraction, self-confidence, and total academic self-esteem. In this study it would appear that when parents gave their child the right nourishment and encouragement, the child had higher academic self-esteem (Warash \& Markstrom). 
Johnson, Johnson, and Taylor (2001) conducted a study using 34 high-ability students from four fifth grade classes at a large Midwestern suburban elementary school. The students were randomly assigned to either a cooperative or an individualistic condition. Each teacher spent half the time in the cooperative condition and half the time in the individualistic condition. All of the subjects participated in six 55 minute instructional sessions. The subjects in both conditions studied the same unit, "The Interdependence of Living Things," which was taken from the Addison-Wesley Level five sciences textbook (Johnson et al.). Two teachers participated in the study. The teachers received 30 hours of training in structuring cooperative and individualistic learning and were given materials and guidelines for each instructional session. The independent variables were cooperative versus individualistic learning and the dependent variables consisted of achievement and the attitudes of the children. Two research assistants observed each condition daily to verify that both conditions were operating correctly. The results concluded that the academic self-esteem of the high-ability students in the cooperative condition was higher than that of the high-ability students in the individualistic condition.

Burnett (1998) conducted a study which aimed to develop and validate an instrument to be used by teachers to measure the frequency of the behaviors associated with self-esteem. The Behaviors Indicative of Self-Esteem (BIOS) (Burnett) was used and then evaluated for the instruments' reliability and concurrent validity. The sample included 317 students in third to seventh grades of middle class studies in metropolitan elementary school. Ten teachers and educators were asked to respond to the question, "What behaviors do children with high and low self-esteem exhibit?" Their response and 
discussions resulted in a list of 32 behaviors that they believed were indicative a high self-esteem. Some of the behaviors included the child showing confidence in making a decision, initiating communication, open with others, was organized and responsible, appeared comfortable with routines, and was attention seeking. This study will add to the academic self-esteem research.

Kemple, David, and Wang (1996) conducted a study on preschoolers' creativity, shyness, and self-esteem. It has been suggested that the low self-esteem of the shy person leads them to enter social situations fearing that they will lack the social competence to perform appropriately, and that they will be negatively evaluated by others (Crozier, 1981). The study was conducted on a total of 64 four and five year-old children, their mothers, and their daycare head teachers. In this study, various assessments were used to measure self-esteem, including teacher ratings on the child's self-esteem. Mothers and teachers also completed a measure of the child's general self-esteem. Teachers completed the Child Behavior Inventory (Schaefer \& Edgerton, 1978), a 60-item 5-point Likert-type scale assessing a variety of classroom behaviors. Reliability and validity data supported the usefulness of the scale in studies of children's adaptation in the early childhood classroom (Schaefer, 1981; Schafer \& Edgerton, 1983). The results of this study suggest that the relationship between shyness and creativity in older children and adults exists in the preschool years as well. Additionally, shyness predicted low creativity ratings in early childhood when the effect of self-esteem was statistically removed. Lower self-esteem and shyness of children indeed influenced each other, such that the less self-confidence a child felt, the more likely he or she hesitated to engage in social interactions. 
Beauchamp-Fuchs (1996) conducted a study on preschoolers inferred self-esteem. The study consisted of 94 children from two Midwestern Head Start programs. The Behavioral Rating Scale of Presented Self-Esteem in Young Children (Haltiwanger, 1989) was used to identify behavioral expressions of global self-esteem as described by preschool teachers (Harter, 1990). The scale consists of bipolar descriptions of behavior. The behavior consisted of the child tolerating frustration of his or her mistakes. Respondents rated each item on a 4-pont scale, and the item scores were summed for the total scale score. Higher scores were to indicate more positive self-esteem. The results included that the teachers tended to rate the children's self-esteem positively. Nevertheless, there was considerable variability and adequate range to assess individual differences in inferred self-esteem. There was a finding of gender differences that suggested preschool teachers may see girls as more confident than boys regarding schoolrelated activities (Beaucham-Fuchs).

Enhancing children's self-esteem is an important goal for most preschool programs (Curry \& Johnson, 1990). The major challenges in measuring young children's self-esteem are their difficulties in reflecting about the self and problems relating to the surroundings of the child (Harter, 1983). Preschoolers develop a sense of self through this stage of life.

Self-esteem and academic self-esteem are two important variables to look at in preschoolers. There was little research on academic self-esteem and a lot on self-esteem. The above literature review of these variables clearly defines the definitions of selfesteem and academic self-esteem. The studies demonstrate the knowledge of parental contributions to preschooler's academic self-esteem, cooperative and individualistic 
learning, behaviors associated with self-esteem, creativity and shyness associated with self-esteem, and identifying behavioral expressions of global self-esteem. All of the

study greatly contributed to knowledge on the association of the preschooler's selfesteem and academic self-esteem.

Aggression

A number of investigators have argued that children's early behavior patterns are one of the best predictors of later social - psychological adjustment outcomes (Kupersmidt, Coie, \& Dodge, 1990). Children's use of aggression with age-mates consistently emerges as one of the best predictors of later maladaptation, including peer rejection, delinquency, criminality, mental illness, underachievement, and dropping out of school (Kohlberg, LaCrosse, \& Ricks, 1972; Kupersmidt et al.). In addition to these long-term risks, there is evidence to suggest that children who rely on aggressive tactics with peers develop adjustment problems earlier in the life span (Ladd \& Profilet, 1996). More important, aggressive behavioral styles are predictive of peer rejection during the preschool years (Ladd \& Profilet).

Ladd and Profilet (1996) conducted a study with two cohorts of kindergarten children and their classroom teachers. The two cohorts assessed in this study were part of a larger longitudinal project and were recruited from communities in the Midwestern United States during consecutive school years. The study compared teacher-report measures of young children's aggressive, withdrawn, and prosocial behaviors. The form of aggressive behavior in this study looked at whether the child fights, bullies, kicks, taunts, threatens, and argues with his or her peers. Asocial or withdrawn behaviors refer to children who prefer to play alone. Prosocial behavior was defined as children 
tendencies to be empathic, cooperative, and self-sacrificing with peers and was measured with items that referred to behaviors such as helping, concern, and kindness. The primary aim of this study was to develop a reliable and valid tool for assessing young children's behaviors with peers at school, using teachers as informants. The instrument that was used was the Child Behavior Scale (CBS) (Ladd \& Profilet,). It is also the instrument used in the present study. Trained observers visited classrooms several times per week during the first 10 weeks of the school year to sample the percentage of time children spent in specific classroom behaviors. It was concluded that the data patterns in this investigation provided substantial evidence that suggests that the subscales of the CBS yield reliable and valid information about several types of behavior with samples of young children. Some of the behaviors included aggression with peers, prosocial with peers, asocial with peers, excluded by peers, anxious, and fearful. Each of the six CBS subscales yielded scores that were internally consistent, distinct from other subscales, and relatively stable over time (Ladd \& Profilet). In conclusion, the data provided sufficient evidence of the reliability and validity of the CBS to recommend its use for risk and prevention research with young children.

Walters, Pearce, and Dahms (1957) presented a study to compare with respect to age and gender. The study investigated the number of affectional and aggressive responses evident during self-directed activity periods in a nursery school-kindergarten setting, the frequency with which preschool children initiated contacts by means of both affectional or aggressive behavior, and the individual chosen as recipients of these contacts. Affectional behaviors were defined as behavior directed toward another 
person who indicated warm regard, friendliness, sympathy or helpfulness (Walters et al.). Aggressive behavior in this study was defined as an actual attack or threatened attack upon another person, whether it be by gesture or hostile or provocative language directed toward another child (Walter et al.). The subjects consisted of 124 children attending the Oklahoma A. \& M. College nursery-kindergarten schools. The results of this study concluded that preschool children of the ages three to five years of age were more verbally than physically affectionate. There was also little difference in variation with which physical and verbal aggression was evident. This study was able to differentiate between affectional and aggressive behavior in preschool children.

Physical aggression in children is a major public health problem (Tremblay et al., 2004). Longitudinal studies show that aggressive school child is at very high risk of being violent in adolescence and beyond. Tremblay et. al. conducted a study with 504 children who were followed from five to forty-two months of age to assess the development course of physical aggression. Mothers were interviewed at home. The four measures included physical aggression, child temperament, mothers' quality of parenting, and parent background and family characteristics. The interviews and questionnaires were completed by the parents of the children. The results concluded that the traditional predictors of antisocial behavior during preadolescence, adolescence, and adulthood also predicted high levels of physical aggression. Also the presence of a sibling had the largest impact on the level of physical aggression during early childhood. In conclusion, most children have initiated the use of physical aggression during infancy, and most will learn to use alternatives in the following years before entering primary school. 
Researchers have found that gender is a theme in early childhood aggressive behavior. As early as preschool, boys are rated by their teachers as more likely than girls to engage in physically aggressive behavior, whereas girls are rated more likely than boys to engage in relationally aggressive acts, such as excluding children from the peer group or threatening to revoke friendship (Crick, Casas, \& Mosher, 1997). Giles and Heyman (2005) conducted three studies on young children's beliefs about gender and their aggressive behaviors. The study consisted of three studies. Study 1 looked at 41 preschoolers that were recruited from two Head Start centers serving low-income, ethnically diverse families in urban areas of San Diego County. Study 2 consisted of 40 preschoolers that attended the same Head Start Centers as in study one, but none had participated in study one. Study 3 consisted of 40 preschoolers, 19 boys and 21 girls, who attended one of the same Head Start Centers as in studies one and three but none participated in studies one or two.

Study 1 in the Giles and Heyman (2005) was designed to determine whether gender information would influence children of aggressive behavior. The children were asked to respond to four open ended questions that stimulated their minds to think about relationally aggressive behaviors of genders. The results of Study 1 , suggested that young children view relationally aggressive behaviors as a primary aggressive tactic for girls but not for boys. The study also provided evidence that children have some awareness that gender labels are informative when making predictions about the likely sorts of aggressive behaviors people will engage in (Giles et al).

In Study 2 in the Giles and Heyman (2005), the two main goals was to replicate the results of Study 1 using different methods of gathering information and to compare 
preschoolers' conceptions of the link between gender and aggression with those of children in elementary school (Giles et al.). The results concluded that boys were more likely to engage in physical aggression than in relational aggression.

Study 3 was designed to test the possibility that children's patterns of beliefs about gender would influence their recall of gender and aggression information. It was concluded based on the findings that young children view the actions of boys and girls through gendered lenses, and that the findings were consistent with the previous work documenting children's difficulty recalling information that is inconsistent with their generalized patterns of beliefs about the social world (Bodenhausen, 1988). It also suggested that girls view relational aggression as more mean than do boys. This research provided evidence that even before children reach school-age, they hold beliefs about the relationship between gender and aggression. Gender information was highly salient in the lives of young children, driving not only their own behavior but also their notions of appropriate behavior for other children (Giles \& Heyman).

Kakouros, Maniadaki, and Karaba (2005) conducted a study on aggressive behavior in preschool boys and girls. The study consisted of nursery school teachers who provided anonymously ratings for 925 preschoolers. Age and gender distributions were as follows: mean age $=56.01$ months, standard deviation $=8.9 ; 51.6 \%$ males and $48.4 \%$ females (Kakouros et al.). This study investigated the presence of different forms of aggressive behavior in preschoolers. To measure the preschoolers aggressive behavior the study used an 11-item teacher - completed rating scale that was constructed for the identification of preschoolers exhibiting aggressive behaviors. The five items (hit, throw objects, snatch objects, destroy objects, and argue) constituted the 'Physical Aggression 
Scale'; four items (swear, lie, threat, and steal) constituted the Verbal/Indirect Aggression Scale; and the remaining two items (is liked, is obedient) reflected prosocial behaviors. The items were scored as 0 (not at all), 1 (a little), and 2 (quite a lot).

Participation in the Kakouras et al. (2005) study was anonymous and voluntary. The nursery school teachers were told that the aim of the study was to investigate their perceptions towards children's behavior. The teachers filled out the questionnaires within a few weeks and handed them to the researcher. Nursery school teachers reported that the preschoolers of the sample exhibited Physical Aggression to a greater degree $($ mean $=0.43$, standard deviation $=0.48)$ than Verbal/Indirect Aggression $($ mean $=0.22$, standard deviation $=0.35)($ Kakouros et al.). There were significant main effects of the child's sex on aggressive behavior. In particular, boys were found to behave more aggressively than girls in general, and to score significantly higher on the Physical Aggression and Indirect/Verbal Aggression Scales (Kakouras et al.). Boys were reported to hit, throw, snatch and destroy objects, swear, threat, argue and steal to a greater extent than girls and girls were reported to be more obedient than boys. It seemed, therefore, that extreme levels of certain behaviors, such as hyperactivity, distractibility and impulsivity, can indeed be detected and characterized as "deviant" by nursery school teachers (Kakouras et al.). It was found that nursery school teachers considered "normal" girls as displaying all forms of aggressive behavior less often than boys. Within the framework of social learning theory, it is suggested that aggression might be more tolerated in boys, but discouraged in girls (Tiegar, 1980).

In the Arsenio, Cooperman, \& Lover (2000) study, the preschooler's aggressive peer interactions, emotion-related knowledge, and affective dispositions were studied. 
The specific goal was to examine the extent to which children's emotion knowledge and affective dispositions were connected as well as the relative contributions to the affective sources to aggression and peer acceptance (Arsenio et al.). This study assessed 51 preschoolers who were enrolled in three classrooms from two day-care facilities in a major northeastern urban setting. The measures included observational assessments of children's naturally occurring emotions and aggressive interactions, two individually administered interviews of the preschoolers, a sociometric and peer nomination assessment and an assessment of emotion-related knowledge and teacher assessments of children's social skills and aggression. Teachers rated children's aggressive behavior using an adaptation of Dodge and Coie's (1987) 12-item Aggression Scale. Teachers made their judgments using a 5-point scale (never, rarely, sometimes, often, and almost always).

The results from the Arsenio et al. (2000) study concluded that 44 of the 51 children initiated at least one aggressive act. As expected, boys were significantly more aggressive than girls. Boys were rated as less socially skilled than girls. In summary, children who displayed a higher percentage of baseline anger were more likely to initiate aggression and were less accepted by peers, and a comparable pattern held for displays of baseline happiness (Arsenio et. al.).

Children who tend to blame peers for negative social experiences will likely subscribe to the belief that peers are generally hostile and "rejecting" and, therefore, maintain fairly negative expectations regarding future interactions with such peers. These types of beliefs and expectations have been linked to both physically aggressive behavior and aggression, encouraging cognitive biases in a number of studies. Ladd and 
Profilet (1996) clearly defined the behaviors of aggression in children who interact with their peers. Preschoolers who display positive attitude and a positive and nurturing environment should able to adapt to their perspective classrooms and communities.

In summary, aggression is a unique variable to observe in preschoolers. The previous studies on aggression focused on measures of aggressive behaviors, affectional behaviors, physical aggression behaviors, the association of gender and aggressiveness, and peer interactions in preschoolers. Research suggests that aggressive behavior in preschool children is influenced by gender, peer rejection, affectional attention within the homes of the children, and adaptation in the classroom (Giles \& Heyman, 2005).

\section{Summary}

Preschooler's academic self-esteem is an important factor that could affect children's adaptation to their classrooms. Enhancing children's self-esteem is an important goal for most preschool programs (Curry \& Johnson, 1990; Greenbag, 1990). Aggressive behaviors have become prevalent in the early childhood classroom and could effect a child's adaptation to the classroom. These studies investigated the association between the aggression of preschool children and their academic self-esteem in the classroom. 


\section{Chapter Three}

Methods

The participants in this study consisted of 63 preschoolers (19 three year olds, 21 four year olds, 21 five year olds, and 2 six year olds) who attended West Virginia University Child Development Laboratory (Nursery School) or Pierpont Christian Preschool. The West Virginia University Child Development Laboratory (Nursery School) supports the philosophy of the Reggio Emilia Approach (children working on child-centered projects that are initiated through their own interests), encourages active learning, and develops academic skills in a play environment. The program also develops a learning environment that helps children develop socially, intellectually, physically, and emotionally. The Pierpont Christian Preschool supports a structured program, utilizing the A Beka curriculum, with a strong phonics emphasis. Their goal is to prepare the children for a lifetime of learning and help them grow physically, emotionally, spiritually, socially, and academically. Both preschools support and encourage the children's growth, development, and learning during their preschool years.

The preschoolers were rated by qualified teachers in each facility. At the West Virginia University Nursery School, the teacher of the three year old class rated 16 preschoolers. This teacher has a M.A. in Early Childhood Education, a B.S. in Child Development and Family Studies, and has taught early childhood education for ten years. The four year old teacher rated 19 preschoolers. This teacher has a M.S. in Child Development and Family Studies, M.S.ED. in Early Intervention/Special Education, B.S. in Child Development and Family Studies, two teaching certifications, and has been the head teacher at the Nursery School for 13 years. 
Pierpont Christian Preschool has two teachers who rated preschoolers in this study. The three year old teacher rated 16 preschoolers. This teacher has a B.A. in Early Education, a teacher certification, and has previous experience in other preschools. The four and five year old teacher rated 12 preschoolers. This teacher has as a B.A. in Accounting, A.A. in Business Administration, and is the director of children's ministry at Pierpont Christian Preschool. All four teachers have college degrees and are experienced and qualified in rating and observing preschoolers.

\section{Procedure}

Before data was collected, an application for exemption (see Appendix A) and approval from the Institutional Review Board (see Appendix B) was completed. Cover letters (see Appendix C) were given to the teachers of each classroom which included the purpose of the study, statement that subjects' responses will be kept anonymous and confidential, and a statement indicating that participation in the study was voluntary. The cover letter also instructed teachers on how to rate the preschoolers on the Child Behavior Scale (CBS) and the Behavioral Academic Self-Esteem Rating Scale (BASE). The teachers in both facilities completed the studies within the same two week time period.

Permission letters (see Appendix D) were obtained from the directors of the West Virginia University Child Development Laboratory and the Pierpont Christian Preschool to conduct the study.

Before using the CBS, a request and approval (see Appendix E) was obtained from the developer of the CBS from Arizona State University. The (CBS) (see Appendix F) was used to rate preschooler's aggressiveness. The preschooler's academic self-esteem was rated by using the BASE (see Appendix G). 


\section{The Child Behavior Scale}

The Child Behavior Scale (CBS) is a teacher report measure which assesses the behavior of young children from ages 4 to 6 years in peer contexts, such as classrooms. This scale consists of options: (1) doesn't apply, (2) applies sometimes, and (3) certainly applies. The CBS yields scores of reliable and valid information about several types of behavior with samples of young children (Ladd \& Profilet, 1996). The CBS is comprised of subscales which represent six dimensions of young children's behavior in peer settings. Higher scores on the CBS imply that the child exhibits certain behaviors. The six subscales (number of items) are labeled: (a) aggressive with peers (7), (b) prosocial with peers (7), (c) excluded by peers (7), (d) asocial with peers (6), (e) hyperactivedistractible (4), and (f) anxious-fearful (4). Collectively, the subscales provide measures of several behaviors that can be considered indicators of interpersonal 'risk' and 'competence' in young children (Ladd \& Profilet).

This study only used the aggressive with peers subscale. These specific items and behaviors are fighting, bullying, kicking, biting, hitting, taunting, teasing, threatening, arguing, and being aggressive. Aggressive with peers subscale is defined as a behavior likely to harm peers and included items to measure the child's physical and verbal forms of aggression (Ladd \& Profilet). In the Ladd and Profilet study, the internal consistency of each subscale was estimated with Cronbach's alpha. Alphas of this magnitude and consistency suggest that all six subscales were reliable in the sense that each contained items that produced relatively homogeneous response patterns. The CBS shows considerable promise as a tool that can be used to gather reliable and valid data on several forms of peer behavior with samples of young children (Ladd \& Profilet). 
The Behavioral Academic Self-Esteem (BASE) Rating Scale

Coopersmith and Gilberts (1982) developed the Behavioral Academic Self-Esteem (BASE) Scale to measure students classroom academic self-esteem and behavior in five areas. The BASE is a 16-item teacher or parent observation scale which assesses the academic self-esteem of preschool children to junior high school children. This scale consists of the teachers responding by selecting never, seldom, sometimes, usually, or always. The BASE has five subscales that measure student initiative (six items), social attention (three items), success/failure (two items), social attraction (three items), and self-confidence (two items). The first subscale, student initiative, measures a child's willingness to learn in the classroom. The social attention subscale measures the child's attentiveness in the classroom. The success/failure subscale measures of the child's acceptance as a student in the classroom. The social attraction subscale measures a child's interaction amongst his or her peers. The last subscale, self-confidence, measures the child's self-respect in the classroom. All subscales were used in this study. All of the subscales are totaled (sixteen total questions) and the child's overall academic selfesteem is calculated. The BASE scale is hand scored and the children are classified as having higher academic self-esteem or lower academic self-esteem scores. The total range of possible scores on the BASE ranges from 1 to 80 , with the lowest being lower academic self-esteem and higher being higher academic self-esteem.

In the Warash and Markstrom (2001) study, reliability of the measure was assessed according to Cronbach's alphas and found to be .93 for student initiative, .64 for social attention, .97 for success / failure, .85 for social attraction, .83 for self-confidence, and .93 for the total BASE score. The 16-item BASE has been recommended as a 
measure of inferred self-esteem with preschoolers. In a review of the BASE, it has been recommended that this is the best teacher report instrument (Hughes, 1984). The BASE relates to the measurement of self-esteem, which accounts for social desirability, method variance, and construct validity. 


\section{Chapter Four}

Results

There were 63 preschoolers in this study ranging from the ages three to six years of age in which four teachers rated their student initiative, social attention, success/failure, social attraction, self-confidence on the BASE and their aggressiveness with peers on the CBS. There were a total of 30 female and 33 male preschoolers.

\section{Statistical Analysis}

First, a general description of the sample was run examining the distribution of ages and sex by the raters (see Table 1). Rater 1 rated seven males and nine females. The total sample was $25.40 \%$. Rater 2 rated ten males and nine females (19 preschoolers) in the ages of 5 four year olds, 12 five year olds, and 2 six year olds. The total sample was $30.16 \%$. Rater 3 rated seven males and nine females (16 preschoolers) in the ages of three year olds and 13 four year olds. The total sample was $25.40 \%$. Rater 4 rated nine males and three females (12 preschoolers) in the ages of 3 four year olds and 9 five year olds. The total sample was $19.05 \%$.

Due to the possibility of differences between raters stemming from training and sample composition, central tendencies and descriptive were computed for each variable at both total sample level and the rater (see Table 2). These indicated that the possible significant differences existed between raters which warranted closer attention before proceeding further. On each of the five subscales on the BASE, a total mean was distributed for each rater. The total mean score for student initiative was 25.13 .

Significant differences between raters were then examined using a series of oneway ANOVA's due to cell-size and violations in normality assumptions apparent in 
visual inspections of each variable's patterns distribution. Raters were used as the independent variable. Findings indicate that significant mean differences exist between raters on the variables for student initiative, success/failure $(\mathrm{p}<.01)$, social attraction $(\mathrm{p}<.01)$ and aggressiveness with peer exists $(\mathrm{p}<.01)($ see Table 3$)$.

Tukey's HSD was then used in post-hoc analyses to examine specific rater differences (see Table 4). On student initiative, rater 1 rated lower than rater 2. The difference was -5.65 and the significance was 0.0021 . On success/failure, rater 1 rated lower than rater 2. On social attraction, rater 1 rated lower than rater 2 and rater 2 rated higher than rater 4 . Raters 1 and 2 had a difference of -2.74 and $(p=0.0142)$. Raters 2 and 4 had a difference of 2.99 and a significance of 0.0137 . These findings indicate that, rater 1's scores were significantly lower than rater 2's scores in regards to student initiative, success/failure, and social attraction. Since there is no way to check inter-rater reliability scores, there is no conclusive evidence that this may not be actually representative of actual sample differences. Additionally, Rater 2 and Rater 4 differed on social attraction. In general the significant differences were seen between Rater 1 and Rater 2. In particular these raters differed on student initiative $(\mathrm{p}<.01)$, social attention $(\mathrm{p}<.01)$, and success/failure $(\mathrm{p}<.05)$ That is, preschoolers scored by each rater may possess actual differences. However, due to these differences it appears prudent to include information about who provided each rating in subsequent models.

Correlations were then computed; both for the overall sample and independently for each rater (see Table 5). Raters were dummy coded where $0=$ all others providing ratings and $1=$ rater who provided rating. Social attention and student initiative had a correlation of .80. Success/failure and student initiative had a correlation of .65 $(\mathrm{p}<.01)$. 
Success/Failure and social attention had a correlation of .68 $(\mathrm{p}<.01)$. Social attraction and student initiative had a correlation of .75. Social attraction and social attention had a correlation of .65. Social attraction and success/failure had a correlation of .61. Selfconfidence and student initiative had a correlation of .87. Self-confidence and social attention had a correlation of .65. Self-confidence and success/failure had a correlation of .48. Self-confidence and social attraction had a correlation of .77. Rater 1 correlations versus all others rated lower in student initiative, social attention, success/failure, social attraction, and self-confidence. Rater 1 rated higher in student initiative, social attention, success/failure, social attraction, and self-confidence. Rater 3 rated higher on student initiative, lower on social attention, higher on success/failure, and lower on selfconfidence.

Finally, one hierarchical regression model was used to examine unique contributions of each variable when in a combinatorial relation with aggressiveness with peers (see Table 6 ). Self-confidence had a $\beta$ of $-.20,(p=.4401)$, and a partial correlation of -.11. In this model, the status of who provided the ratings for aggression with peers was not significant. Social attention, success/failure, and social attraction were each significant when variance from rater status was partial out of the model.

Based on the patterns seen throughout the analyses, it appears that it is important to consider who provided the ratings when looking at relations between preschooler's academic self-esteem and aggressiveness with peers. In analysis (see Tables 1 and 2), it appears that each rater may attach differing values to each type of academic self-esteem behaviors (see Table 1 and Table 6). However, each rater appears to perceive aggressiveness with peers in a similar fashion (see Tables 3 and 4). 
Thus, it appears that social attention, success/failure, and social attraction are relatively consistently related to aggressiveness with peers. These sample perceptions of student initiative in relation to aggressiveness with peers are more complex and contingent. 
Table 1

General Description of the Sample $(N=63)$.

\begin{tabular}{|c|c|c|c|c|c|c|c|c|}
\hline \multirow{2}{*}{ Rater } & & \multirow[b]{2}{*}{ Totals } & \multicolumn{4}{|c|}{ Age } & \multicolumn{2}{|c|}{ Sex } \\
\hline & & & & & 5 & 6 & Males & Females \\
\hline \multirow[t]{3}{*}{1} & $\mathrm{~N}$ & 16 & 16 & 0 & 0 & 0 & 7 & 9 \\
\hline & $\%$ Column & 25.40 & 84.21 & 0 & 0 & 0 & 21.21 & 30.00 \\
\hline & $\%$ Total & & 25.40 & 0 & 0 & 0 & 11.11 & 14.29 \\
\hline \multirow[t]{3}{*}{2} & $\mathrm{~N}$ & 19 & 0 & 5 & 12 & 2 & 10 & 9 \\
\hline & $\%$ Column & 30.16 & 0 & 23.81 & 57.14 & 100 & 30.30 & 30.00 \\
\hline & $\%$ Total & & 0 & 7.94 & 19.05 & 3.17 & 15.87 & 14.29 \\
\hline \multirow[t]{3}{*}{3} & $\mathrm{~N}$ & 16 & 3 & 13 & 0 & 0 & 7 & 9 \\
\hline & $\%$ Column & 25.40 & 15.79 & 61.90 & 0 & 0 & 21.21 & 30.00 \\
\hline & $\%$ Total & & 4.76 & 20.63 & 0 & 0 & 11.11 & 14.29 \\
\hline \multirow[t]{3}{*}{4} & $\mathrm{~N}$ & 12 & 0 & 3 & 9 & 0 & 9 & 3 \\
\hline & $\%$ Column & 19.05 & 0 & 14.29 & 42.86 & 0 & 27.27 & 10.00 \\
\hline & $\%$ Total & & 0 & 4.76 & 14.29 & 0 & 14.29 & 4.76 \\
\hline \multirow[t]{3}{*}{ Total } & $\mathrm{N}$ & 63 & 19 & 21 & 21 & 2 & 33 & 30 \\
\hline & $\%$ Column & 100 & 100 & 100 & 100 & 100 & 100 & 100 \\
\hline & $\%$ Total & 100 & 30.16 & 33.33 & 33.33 & 3.17 & 52.38 & 47.62 \\
\hline
\end{tabular}


Table 2

Central Tendencies and Descriptives

\begin{tabular}{|c|c|c|c|c|c|c|c|c|}
\hline & $M$ & $S E_{\text {mean }}$ & Med. & Mode & STD & Var & Min & $\operatorname{Max}$ \\
\hline \multicolumn{9}{|c|}{ Student initiative } \\
\hline Total & 25.13 & 0.61 & 25 & 30 & 4.84 & 23.44 & 10 & 30 \\
\hline Rater 1 & 22.19 & 1.14 & 22 & 22 & 4.55 & 20.70 & 10 & 29 \\
\hline Rater 2 & 27.84 & 0.81 & 30 & 30 & 3.53 & 12.47 & 18 & 30 \\
\hline Rater 3 & 25.69 & 1.32 & 28.5 & 30 & 5.29 & 27.96 & 16 & 30 \\
\hline Rater 4 & 24.00 & 1.23 & 24 & 24 & 4.26 & 18.18 & 16 & 30 \\
\hline \multicolumn{9}{|c|}{ Social Attention } \\
\hline Total & 12.67 & 0.32 & 13 & 15 & 2.57 & 6.61 & 5 & 15 \\
\hline Rater 1 & 11.88 & 0.65 & 12 & 10 & 2.60 & 6.78 & 5 & 15 \\
\hline Rater 2 & 13.89 & 0.41 & 15 & 15 & 1.79 & 3.21 & 9 & 15 \\
\hline Rater 3 & 12.44 & 0.72 & 13.5 & 15 & 2.87 & 8.26 & 7 & 15 \\
\hline Rater 4 & 12.08 & 0.79 & 12.5 & 12 & 2.75 & 7.54 & 7 & 15 \\
\hline \multicolumn{9}{|c|}{ Success/Failure } \\
\hline Total & 8.38 & 0.22 & 8 & 10 & 1.73 & 2.98 & 2 & 10 \\
\hline Rater 1 & 7.38 & 0.46 & 8 & 8 & 1.86 & 3.45 & 2 & 10 \\
\hline Rater 2 & 9.21 & 0.29 & 10 & 10 & 1.27 & 1.62 & 6 & 10 \\
\hline Rater 3 & 8.75 & 0.43 & 10 & 10 & 1.73 & 3.00 & 4 & 10 \\
\hline Rater 4 & 7.92 & 0.43 & 8 & 8 & 1.51 & 2.27 & 6 & 10 \\
\hline \multicolumn{9}{|c|}{ Social Attraction } \\
\hline Total & 12.05 & 0.35 & 12 & 15 & 2.80 & 7.82 & 3 & 15 \\
\hline Rater 1 & 11.00 & 0.76 & 11 & 11 & 3.03 & 9.20 & 3 & 15 \\
\hline Rater 2 & 13.74 & 0.48 & 15 & 15 & 2.08 & 4.32 & 9 & 15 \\
\hline Rater 3 & 12.06 & 0.79 & 13.5 & 15 & 3.15 & 9.93 & 6 & 15 \\
\hline Rater 4 & 10.75 & 0.46 & 11 & 12 & 1.60 & 2.57 & 8 & 13 \\
\hline \multicolumn{9}{|c|}{ Self-Confidence } \\
\hline Total & 8.60 & 0.22 & 9 & 10 & 1.76 & 3.08 & 3 & 10 \\
\hline Rater 1 & 8.06 & 0.44 & 8 & 8 & 1.77 & 3.13 & 3 & 10 \\
\hline Rater 2 & 9.47 & 0.26 & 10 & 10 & 1.12 & 1.26 & 6 & 10 \\
\hline Rater 3 & 8.38 & 0.57 & 10 & 10 & 2.28 & 5.18 & 4 & 10 \\
\hline Rater 4 & 8.25 & 0.41 & 8 & 8 & 1.42 & 2.02 & 6 & 10 \\
\hline \multicolumn{9}{|c|}{ Aggressive with peers } \\
\hline Total & 7.95 & 0.21 & 7 & 7 & 1.70 & 2.88 & 7 & 13 \\
\hline Rater 1 & 8.00 & 0.39 & 7 & 7 & 1.55 & 2.40 & 7 & 12 \\
\hline Rater 2 & 7.74 & 0.40 & 7 & 7 & 1.73 & 2.98 & 7 & 13 \\
\hline Rater 3 & 8.38 & 0.53 & 7 & 7 & 2.13 & 4.52 & 7 & 13 \\
\hline Rater 4 & 7.67 & 0.36 & 7 & 7 & 1.23 & 1.52 & 7 & 10 \\
\hline
\end{tabular}




\section{Table 3}

ANOVA Comparisons of Rater Scores on Student Initiative, Success/Failure, Social Attraction, Self-Confidence, and Aggressiveness with Peer $(N=63)$.

\begin{tabular}{llrrrrl} 
Variable & & SS & df & MS & F & Sig. \\
\hline Student Initiative & Between & 298.58 & 3 & 99.53 & 5.09 & 0.0034 \\
& Within & 1154.40 & 59 & 19.57 & & \\
Total & 1452.98 & 62 & & & \\
Social Attention & Between & 43.61 & 3 & 14.54 & 2.34 & 0.0825 \\
& Within & 366.39 & 59 & 6.21 & & \\
Total & 410.00 & 62 & & & \\
& Between & 34.03 & 3 & 11.34 & 4.44 & 0.0070 \\
Social Attraction & Within & 150.82 & 59 & 2.56 & & \\
& Total & 184.86 & 62 & & & \\
& Between & 91.99 & 3 & 30.66 & 4.60 & 0.0058 \\
Self-Confidence & Within & 392.87 & 59 & 6.66 & & \\
& Total & 484.86 & 62 & & & \\
& Between & 21.41 & 3 & 7.14 & 2.48 & 0.0698 \\
Aggressive with peers & Within & 169.67 & 59 & 2.88 & & \\
& Total & 191.08 & 62 & & & \\
& Between & 4.76 & 3 & 1.59 & 0.54 & 0.6586 \\
& Within & 174.10 & 59 & 2.95 & & \\
\hline
\end{tabular}


Table 4

Tukey's HSD Comparisons of Unique Differences Between Raters Scores on Student

Initiative, Success/Failure, Social Attraction, and Aggressiveness with Peer $(N=63)$.

\begin{tabular}{|c|c|c|c|c|c|}
\hline \multirow{2}{*}{$\begin{array}{l}\text { Variable } \\
\quad \text { Comparison }\end{array}$} & \multirow[b]{2}{*}{ Difference } & \multirow[b]{2}{*}{ SE } & \multirow[b]{2}{*}{ Sig. } & \multicolumn{2}{|c|}{$95 \%$ Confidence Interva } \\
\hline & & & & Lower & Upper \\
\hline \multicolumn{6}{|l|}{ Student Initiative } \\
\hline 1 to 2 & -5.65 & 1.50 & 0.0021 & -9.62 & -1.69 \\
\hline 1 to 3 & -3.50 & 1.56 & 0.1250 & -7.63 & 0.63 \\
\hline 1 to 4 & -1.81 & 1.69 & 0.7072 & -6.28 & 2.65 \\
\hline 2 to 3 & 2.15 & 1.50 & 0.4827 & -1.81 & 6.12 \\
\hline 2 to 4 & 3.84 & 1.63 & 0.0972 & -0.47 & 8.15 \\
\hline 3 to 4 & 1.69 & 1.69 & 0.7505 & -2.78 & 6.15 \\
\hline \multicolumn{6}{|l|}{ Success/Failure } \\
\hline 1 to 2 & -1.84 & 0.54 & 0.0068 & -3.27 & -0.40 \\
\hline 1 to 3 & -1.38 & 0.57 & 0.0820 & -2.87 & 0.12 \\
\hline 1 to 4 & -0.54 & 0.61 & 0.8115 & -2.16 & 1.07 \\
\hline 2 to 3 & 0.46 & 0.54 & 0.8308 & -0.97 & 1.89 \\
\hline 2 to 4 & 1.29 & 0.59 & 0.1366 & -0.26 & 2.85 \\
\hline 3 to 4 & 0.83 & 0.61 & 0.5261 & -0.78 & 2.45 \\
\hline \multicolumn{6}{|l|}{ Social Attraction } \\
\hline 1 to 2 & -2.74 & 0.88 & 0.0142 & -5.05 & -0.42 \\
\hline 1 to 3 & -1.06 & 0.91 & 0.6513 & -3.47 & 1.35 \\
\hline 1 to 4 & 0.25 & 0.99 & 0.9942 & -2.36 & 2.86 \\
\hline 2 to 3 & 1.67 & 0.88 & 0.2341 & -0.64 & 3.99 \\
\hline 2 to 4 & 2.99 & 0.95 & 0.0137 & 0.47 & 5.50 \\
\hline 3 to 4 & 1.31 & 0.99 & 0.5466 & -1.29 & 3.92 \\
\hline
\end{tabular}




\section{Table 5}

Bivariate Correlations $(N=63)$

\begin{tabular}{|c|c|c|c|c|c|c|c|c|c|c|}
\hline & 1 & 2 & 3 & 4 & 5 & 6 & 7 & 8 & 9 & 10 \\
\hline $\begin{array}{l}\text { 1. Aggressive with } \\
\text { peers }\end{array}$ & 1.00 & & & & & & & & & \\
\hline 2. $\operatorname{Sex}^{1}$ & -.01 & 1.00 & & & & & & & & \\
\hline 3. Student Initiative & -.22 & $.27 *$ & 1.00 & & & & & & & \\
\hline 4. Social Attention & $-46^{* *}$ & .22 & $.80 * *$ & 1.00 & & & & & & \\
\hline 5. Success/Failure & $-47 * *$ & .23 & $.65^{* *}$ & $.68^{* *}$ & 1.00 & & & & & \\
\hline 6. Social Attraction & -.11 & .14 & $.75^{* *}$ & $.65^{* *}$ & $.61^{* *}$ & 1.00 & & & & \\
\hline 7. Self-Confidence & -.14 & .22 & $.87 * *$ & $.65 * *$ & $.48^{* *}$ & $.77 * *$ & 1.00 & & & \\
\hline $\begin{array}{l}\text { 8. Rater } 1 \text { versus all } \\
\text { others }^{2}\end{array}$ & .02 & .10 & $-36^{* *}$ & -.18 & $-34 *$ & -.22 & -.18 & 1.00 & & \\
\hline $\begin{array}{l}\text { 9. Rater } 2 \text { versus all } \\
\text { others }^{3}\end{array}$ & -.08 & .00 & $.37^{* *}$ & $.32 *$ & $.32 *$ & $.40^{* *}$ & $.33 * *$ & $-38 * *$ & 1.00 & \\
\hline $\begin{array}{l}\text { 10. Rater } 3 \text { versus all } \\
\text { others }{ }^{4}\end{array}$ & .15 & .10 & .07 & -.05 & .13 & .00 & -.08 & $-34 * *$ & $-38 *$ & 1.00 \\
\hline
\end{tabular}

$* p<.05 ; * * p<.01$

${ }^{1}$ Dummy coded where Boys $=0$ and Girls $=1$

${ }^{2,3,4}$ Dummy coded where Rater $=1$ and all others $=0$ 


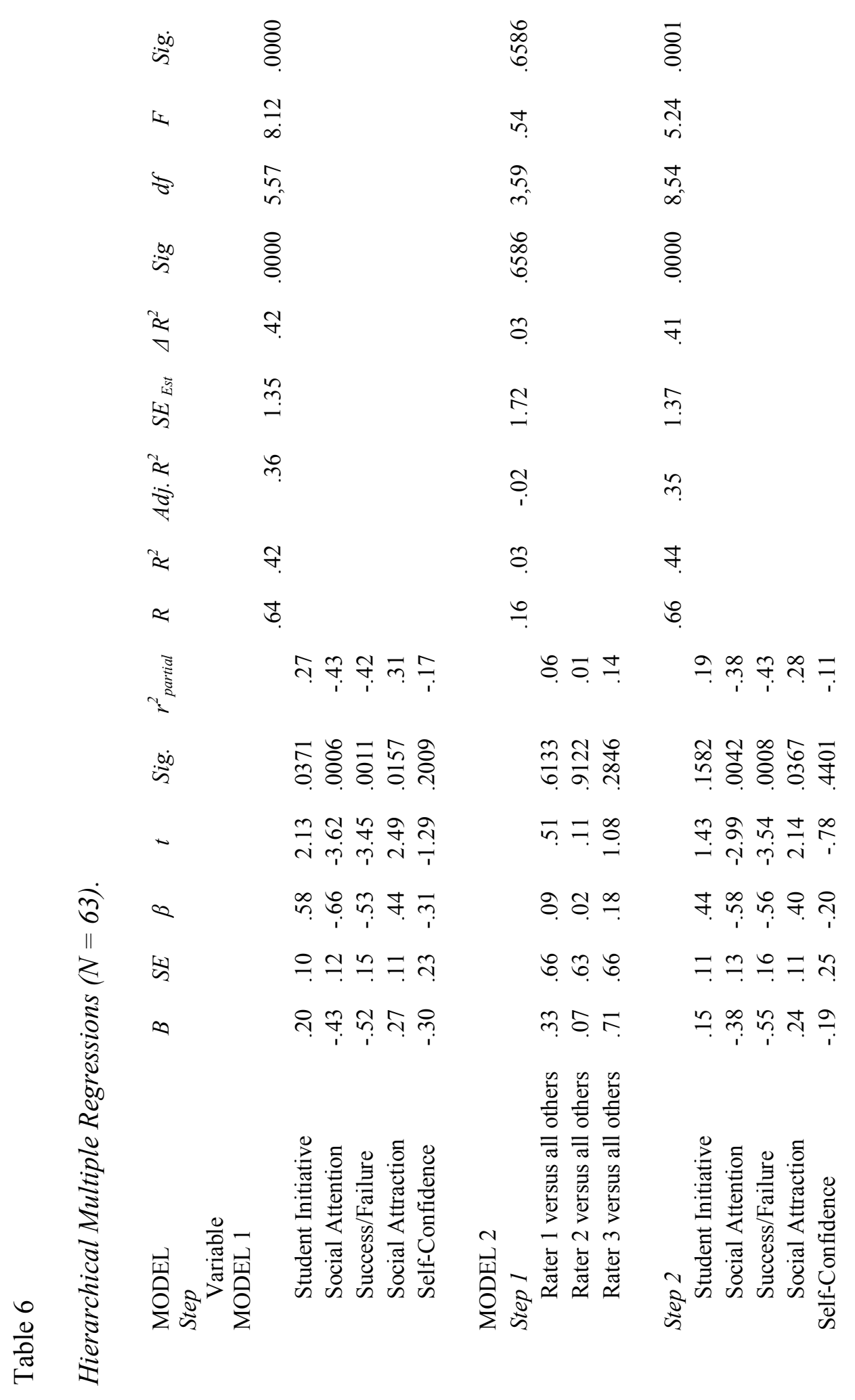




\section{Chapter Five}

\section{Discussion}

This study investigated academic self esteem and aggression of preschoolers in an academic setting. Results of the study supported various aspects of the five hypotheses of aggression. The difference in the rater's scores was an unexpected finding in this study. Rater 2 from the West Virginia University Laboratory Nursery School had scores that were quite different from the scores of the other three raters. This result was statistically managed so that the researcher could look for findings dealing with aggression and academic self-esteem. Social attention, success/failure and social attraction were found to be related to aggressiveness with peers.

For preschoolers, aggressiveness with peers includes fighting with other children, bullying, kicking, biting, hitting other children, arguing with peers, taunting and teasing other children, or threatening other children. Significant findings in this study included higher CBS scores on the aggressiveness with peers subset associated with lower sores on the social attention subscale of the BASE. Usually children that are more aggressive are often seeking attention (Ladd, 1996). This was not the case for the preschoolers of these two preschools. Children in this study scored lower on the social attention subscale which indicates they were not seeking social attention by means of aggression. In the laboratory school this might be explained by the large number of student teachers completing placements at the school. Children receive a lot of individual attention from adults and do not have to use aggression as a means to gain attention for their personal needs. The other school is quite structured and there could be major repercussions for those children not responding with good manners. Sometimes children will behave out of fear for the 
consequences. There is really no way of knowing that this was the case for the school considered to be more strict.

Higher aggressive scores on the CBS subset of aggressiveness with peers was associated with lower scores on the success/failure subscale of the BASE. The success / failure factor measures the student's capability to handle criticism and failure. A low rating on the success / failure subscale suggests a fear of failure. Children who display aggressive behaviors could be avoiding teacher instruction and classroom rules because they fear failure. Sometimes children will not try and react to certain situations more aggressively because of low self-esteem. In the preschool using the A Beca program, children are completing worksheets which are not considered developmentally appropriate for preschoolers. The National Association for the Education of Young Children (NAEYC) has developed a position statement on developmentally appropriate practice and refers to the inappropriateness of the use of worksheets. Children can feel frustrated when they are doing activities that are difficult for them. In this study, children who felt they could not successfully do the worksheets, might react in an antisocial manner which could be construed as aggressive.

Higher scores on the CBS aggressive with peers' subset were associated with higher scores on the social attraction subscale of the BASE. The social attention factor measures how well a child fits into the environment of the classroom. Children who scored lower on this subscale are children who do not need attention in unacceptable ways. More aggressive children are more noticeable in the classroom and this may explain their high social attraction. These children are very young and often it is the first time they are in an academic setting which means their expectations are not set as to what 
classroom behavior should look like. In this study, children who were rated more aggressive with peers were also children who gained attention in this manner.

Previously, the hypothesis stated that aggressiveness with peers should be associated with academic self-esteem. Therefore, there were various analyses observed and found that student initiative, success / failure, social attention, social attraction, selfconfidence were associated with aggressive behaviors of peers in preschool classrooms.

In summary, previous research has suggested that parents who gave their child the right nourishment and encouragement, the child had higher academic self-esteem (Warash \& Markstrom, 2001). Therefore, it was expected that the child will experience lower aggressive acts towards peers. In contrast, in the Giles and Heyman (2005) study, aggressive behavior in preschool children was influenced by gender, peer rejection, and adaptation in the classroom. Arsenio et al. (2000) found that boys are significantly more aggressive than girls. Therefore, preschooler's aggressive behaviors and academic selfesteem is associated with their interactions and their behaviors.

\section{Limitations of Study}

This study was conducted at two separate preschool settings. One was a developmental laboratory school and the other was a Christian school using the A Beka program. Both settings provided a learning environment for the children. Having different teachers rate the children was a definite limitation. There was great variation among the raters which may be due to personality differences and/or differences in perceptions. Two of the raters from the same preschool had extreme differences in how they rated the children on the CBS and the BASE. One of the teachers rated the three year old morning class and the other teacher rated a four year old afternoon class. 
Teachers view children from their own perspective and intertwine their own personal beliefs into these ratings. This was a major limitation of this study. Teachers from the same preschool which has the same philosophy in the classrooms should have a more consistent rating of the children. The ratings were all done at the end of the year when children have adjusted to the schedule and routine. The differences can only be explained by the personality differences and the overall more negative outlook of one of the teachers.

A larger sample would have also been more beneficial. This would have provided a wider range of ratings from more teachers. Finally, it would have been helpful if the researcher would have completed an observation on each classroom which would have included a teacher interview. This would have given a little more credibility to the teacher's ratings if the researcher would have been familiar with each teacher and program.

In summary, the study did show that teachers rate preschoolers on aggressive behavior and academic self-esteem in different ways. Additional research is also needed on academic self-esteem to provide an adequate understanding of preschooler's achievements and behaviors in a classroom setting. The present study contributes to the knowledge-base on aggressiveness of preschoolers and their academic self-esteem. The study will add to the research on preschooler's academic self-esteem displayed in the classrooms. Academic self-esteem will be part of the research literature on preschoolers and other age groups. It is important to continue research on self-esteem, academic selfesteem, and aggressive behaviors of preschoolers. 


\section{References}

Arsenio, W.F., Cooperman, S., \& Lover A. (2000). Affective predictors of preschoolers' aggression and peer acceptance: Direct and indirect effects. Developmental Psychology, 36, 438-448.

Beauchamp-Fuchs, K.D. (1996). Preschoolers' inferred self-esteem: The behavioral rating scale of presented self-esteem in young children. The Journal of Genetic Psychology, 157, 204-210.

Behar, L., \& Stringfield, S. (1974). A behavior rating scale for the preschool child.

Bodenhausen, G.V. (1988). Stereotypic biases in social decision making and memory: Testing process models of stereotype use. Journal of Personality and Social

Burnett, P.C. (1998). Measuring behavioral indicators of self-esteem in the classroom. Journal of Humanistic Education \& Development, 37, 1-10.

Carroll, J., Friedrich, D., \& Hund, J. (1984). Academic self-concept and teachers' perceptions of normal, mentally retarded, and learning disabled elementary students. Psychology in the Schools, 21, 343-348.

Coopersmith, S. (1981). The antecedents of self-esteem. San Francisco: Freeman.

Coopersmith, S. \& Gilberts, R. (1982). Behavioral Academic Self-Esteem (BASE) Manuel. Palo Alto, CA: Consulting Psychologist Press.

Crain, W. (2005). Theories of development: Concepts and development $\left(5^{\text {th }}\right.$ Ed.) New Jersey: Pearson Education, Inc.

Crick, N.R., Casas, J.F., \& Mosher, M. (1997). Relational and overt aggression in Preschool. Developmental Psychology, 33, 579-588. 
Crozier, W.R. (1981). Shyness and self-esteem. British Journal of Social Psychology, $20,220-222$.

Curry, N.E. \& Johnson, C.N. (1990). Beyond self-esteem: Developing a genuine sense of human value. Washington, D.C.: National Association for the Education of Young Children.

Dodge, K., \& Coie, J. (1987). Social -information -processing factors in reactive and proactive aggression in children's peer groups. Journal of Personality and Social Psychology, 53, 1146-1158.

Giles, J.W., \& Heyman, G.D. (2005). Young children's beliefs about the relationship between gender and aggressive behavior. Child Development, 76, 107-121.

Greenbag, P. (1990). Ideas that work with young children: Why not academic preschool? (Part 1). Young Children, 45, 70-80.

Haltiwanger, J. (1989, April). Behavioral referents of presented self-esteem in young children scale, Paper presented at the Biennial Meetings of the Society for Research in Child Development, Kansas City, MO.

Harter, S. (1983). Developmental perspectives on the self-system. In E. M. Hetherington (Ed.), Handbook of child psychology: Vol. 4 Socialization, personality, and social development ( $4^{\text {th }}$ ed., pp. 275-386). New York: Wiley.

Harter, S. (1990). Causes, correlates, and the functional role of global self-worth: A life-span perspective. In R.J. Sternberg \& J. Kolligan (Eds.), Competence considered (pp.67-97). New Haven, CT: Yale University Press. 
Hughes, H.M., \& Pugh, R. (1984). The behavioral rating form-revised: A parent-report measure of children's self-esteem. Journal of Clinical Psychology, 40, 10011005.

Johnson, D.W., Johnson, R.T., \& Taylor, B. (2001). Impact of cooperative and individualistic learning on high-ability students' achievement, self-esteem, and social acceptance. The Journal of Social Psychology, 133, 839-844.

Kakouros, E., Maniadaki, K., \& Karaba, R. (2005). The relationship between attention deficit/hyperactivity disorder and aggressive behaviour in preschool boys and girls. Early Child Development and Care, 175, 203-214.

Kemple, K.M., David, G.M., \& Wang, Y. (1996). Preschoolers' creativity, shyness, and self-esteem. Creativity Research Journal, 9, 317-326.

Kohlberg, L., LaCrosse, J., \& Ricks, D. (1972). The predictability of adult mental health from childhood. In B. Wolman (Ed), Manuel of child psychopathology (pp. 1217 - 1283). New York: McGraw-Hill.

Kupersmidt, J.B., Coie, J.D., \& Dodge, K.A. (1990). The role of poor peer relationships in the development of disorder. In S.R. Asher \& J.D. Coie (Eds.), Peer rejection in childhood (pp.274-305). New York: Cambridge University Press.

Ladd, G.W. \& Burgess, K.B. (1999). Charting the relationship trajectories of aggressive, withdrawn, and aggressive/withdrawn children during early grade school. Child Development, 70, 910-929.

Ladd, G.W., Price, J.M., \& Hart, C.H. (1990). Preschoolers' behavioral orientations and patterns of peer contact: Predictive of peer status? In S.R. Asher \& J.D. Coie (Eds.), Peer rejection in childhood (pp. 90-115). New York: Cambridge 
University Press.

Ladd, G.W., \& Profilet, S.M. (1996). The child behavior scale: A teacher-report Measure of young children's aggressive, withdrawn, and prosocial behaviors. Developmental Psychology, 32, 1008-1024.

Maselli, D., \& Veaco, L. (1984). Aggressive behavior of the preschool child. Education, $104,385-388$.

National Association for the Education of Young Children (NAEYC). Promoting excellence in early childhood education. Retrieved November 3, 2006, from http://www.naeyc.org/about/

Parke, R.D., \& Slaby, R.G. (1983). The development of aggression. In E.M. Hetherington (Ed.), Handbook of child psychology: Vol.4 socialization, personality, social, development (4th ed., pp. 547-641). New York: Wiley.

Schaefer, E.S., \& Edgerton, M. (1978). A method and a model for describing competence and adjustment: A preschool version of the Classroom Behavior Inventory. (ERIC Document Reproduction Service No. ED 183 262).

Schaefer, E.S. (1981). Development of adaptive behavior. In M.J. Begib, C. Haywood, \& H.L. Garber (Eds.), Psychosocial influences in retarded development (Vol.I,pp.155-178). Baltimore: University Park Press.

Schaefer, E.S., \& Edgerton, M. (1983, August). Unified model for academic competence, social adjustment, and psychopathology. Paper presented at the American Psychological Association, Anaheim, CA.

Tieger, T. (1980). On the biological differences of sex differences of sex differences in aggression. Child Development, 51, 943-963. 
Tremblay, R.E., Nagin, D.S., Sequin, J.R., Zoccolillo, M., Zelazo, P.D., Boivin, M., Perusse, D., \& Japel, C. (2004). Physical aggression during early childhood: Trajectories and predictors. Pediatrics, 114, 43-49.

Walters, J., Pearce, D., \& Dahms, L. (1957). Affectional and aggressive behavior of preschool children. Child Development, 28, 15-26.

Warash, B.G., \& Markstrom, C.A. (2001). Parental perceptions of parenting styles in relation to academic self-esteem of preschoolers. Education, 121, 485-494. 
APPENDICES 
APPENDIX A

EXEMPTION FORM 


\section{Applinatian for kxampoinum}

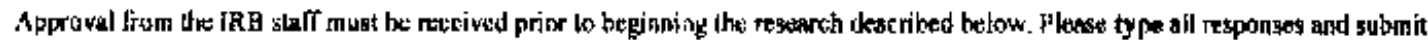

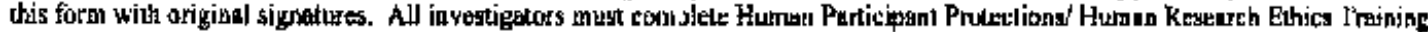

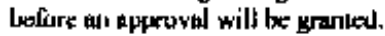

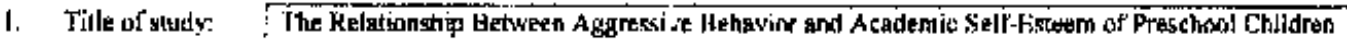

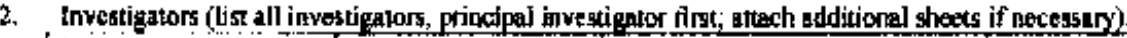

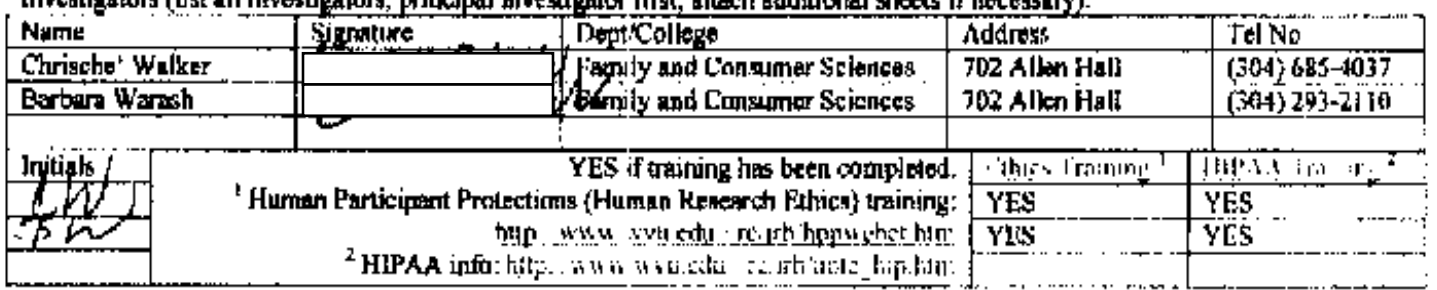

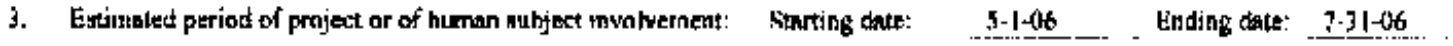

4. Resson for condusting researab

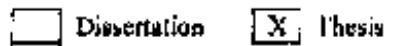

Othẹr

$$
\text { सक्षा }
$$

5. Sorre af thinding (if ppptictbite) Piots

6. Nulmber of projected shbjacts 65 Jurraber of prajpgted records or deta files

6

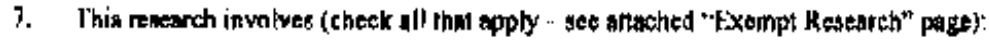

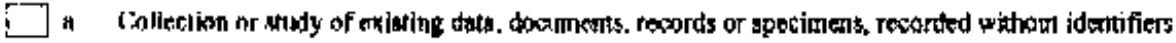

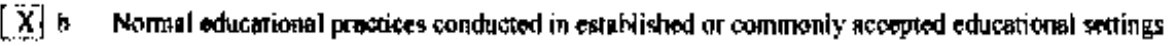

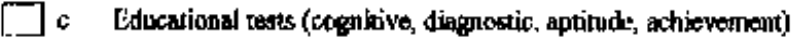

d Dbservoticon of public behouior

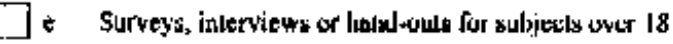

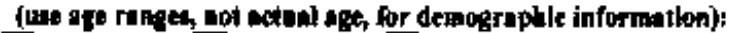
] Mail $\square$ Tolephose $\square$ Perom-loperson

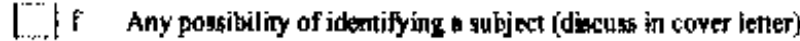

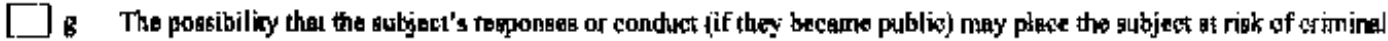

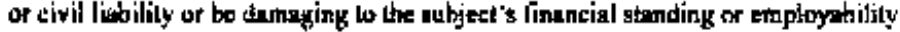

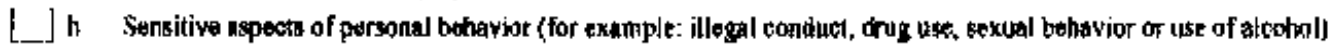

[.] i Ifvestipancer's participation in activities being obserwed

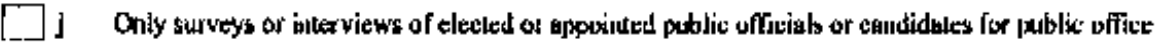

k Mudiotopisy

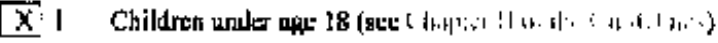

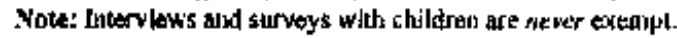

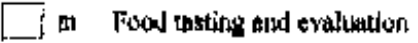

- Research and dementration projucts

- Access to protected health informetion (IPIT) (Ses HIPAA requirements: $\mathrm{i}$ ii,

(M) p Bantige Scales of childon by teachers 
3. Guul wi regandi

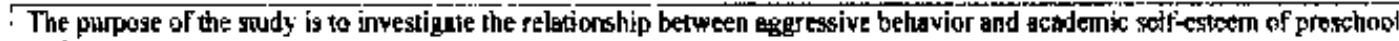

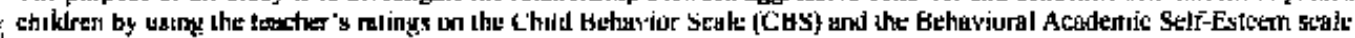
(AASt)

Retigid AFF 20005

9. [Xxplunntion af procedures inwelved in research

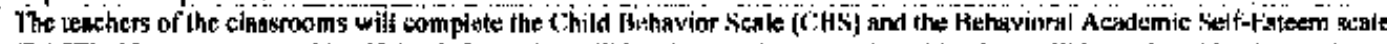

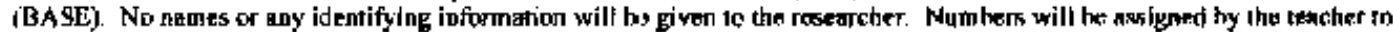

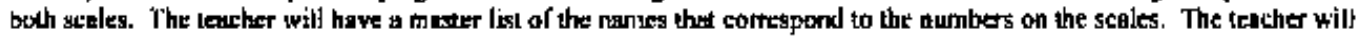
matro the arakes by numbers.

10. Explanation of tonowin figks to human subjacis

Nonte

11. Explanation of how reerds will be kegi

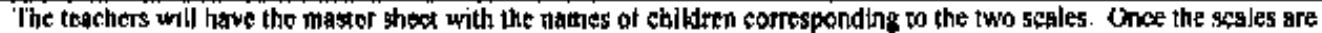

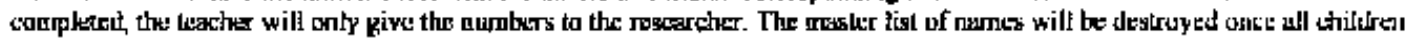

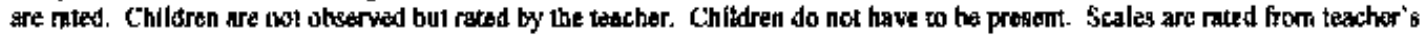

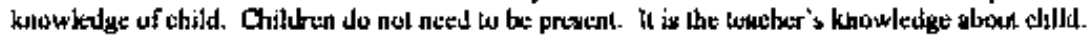

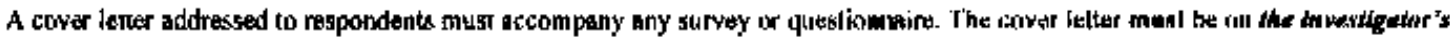
WWU drpartanental lettarkeud and mux inchude the following:

I a starement that the project is research being conducted in partial fuffiltunent of the requirements tor a courst, master's thasls,

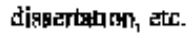

2 Purpose af sthity

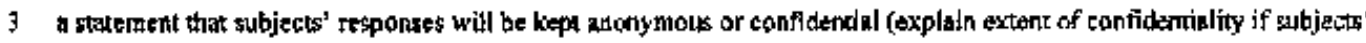

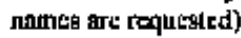

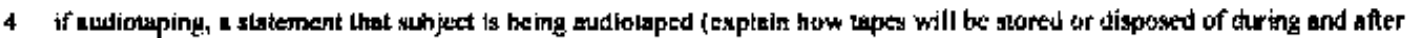
the stipuly)

5 a statement thar subjects do the hate to Bhtwer every quastion

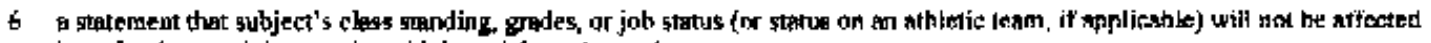

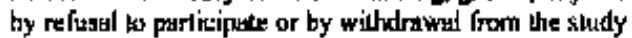

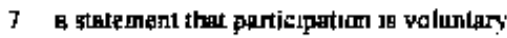

Attachmarls:

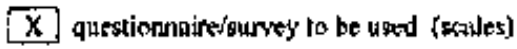

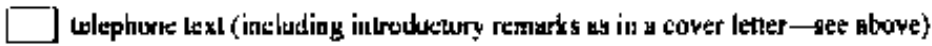

$\mathrm{X}$. covar letter

$X$ permission from external insticuxion, on their lenturtend (if applicatle) 


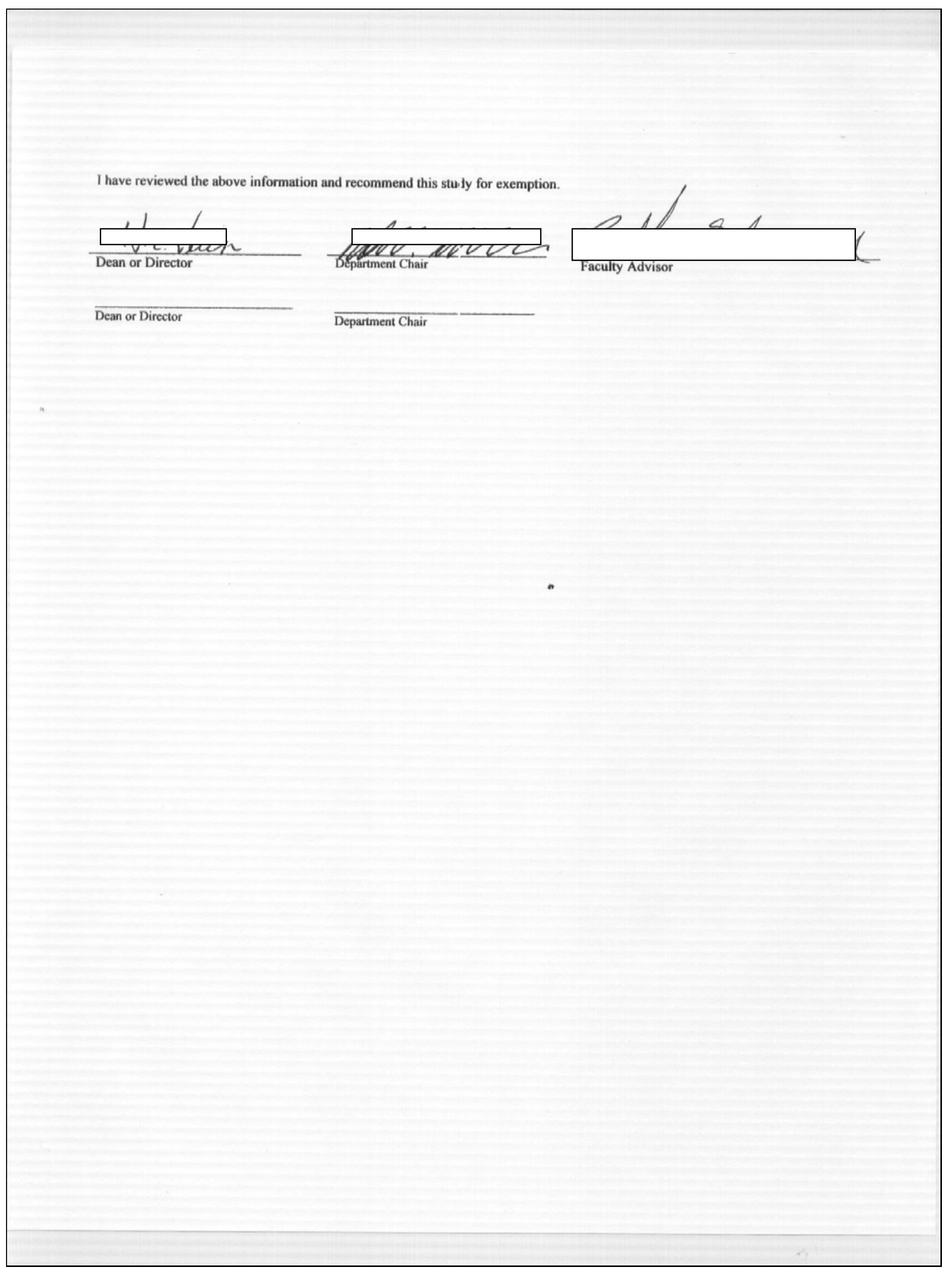


APPENDIX B

IRB APPROVAL FORM 


\section{WescVirginlaUntwersity}

Offrce ol Hegearch Complance

Date: April 20,2006

\section{MEMCRANDLM}

To: Chrische Walker

DCAFCSTomily \& Consumer Sejences

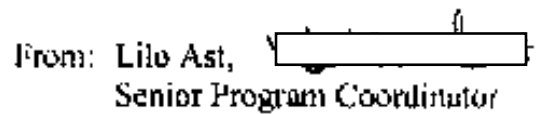

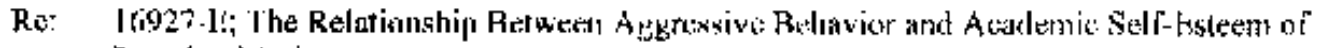
Preschool C'hildren

The Lnstitutional Review Boand for the Protection of Human Research Subjects (]RB) finds the above names research project quili fies iss an exemprion.

This linding will ronain in effect only on the condision thar the research is cartied oux

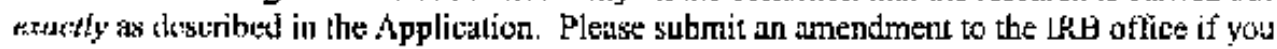
intend to modify or change your sludy in any way. Any anendment mast be reviowed and acknowled bed belure initiating any changes or modifications

Bod wighas for the suecess of your research.

LNALL

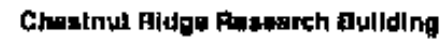

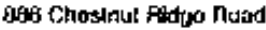

PO Box LE45

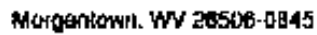

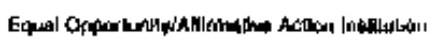


APPENDIX C

COVER LETTER TO TEACHERS 
Dheor Tenedsor',

My nante is Chrisclue' Walker. I am a griatuate student in Chitu Development and

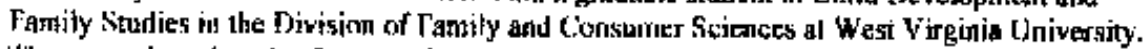

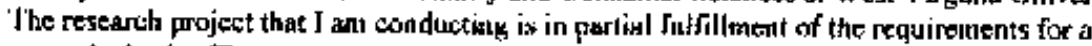

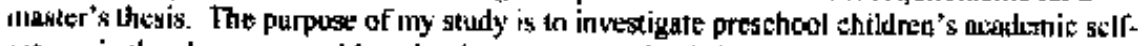

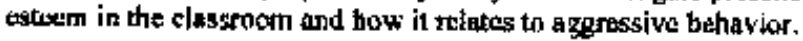

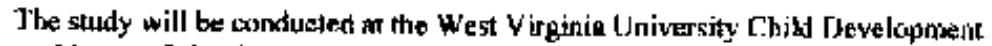
Laboratory Noraery Schuol and at the Petponl Cliristian Preschool. Farticipation in the sucty is

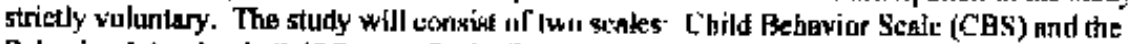

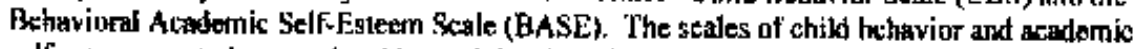

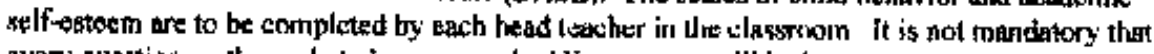

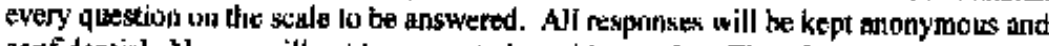
acolfidential. Nemes will not be requested on tillher scales. Therefore, nu narmes or any ulhor identifying information will be used in reparis based on tho results of this sady. Responses apd all other information witt be kept enofidential.

Kefinal lo participate will ant affoct job startus. If you are willing, lo part thipste in this

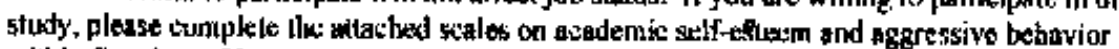

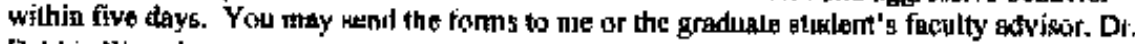
Eobbie Werash.

If yin haw any gutstions regarding my research, please do not hesitnte to call aric at

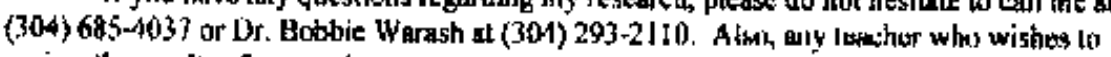

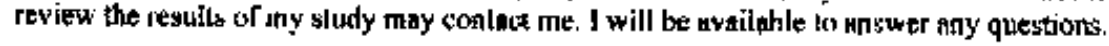

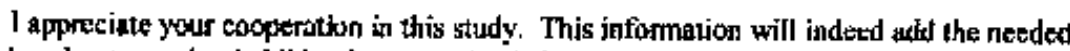

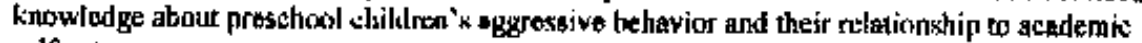
siolf-esteem
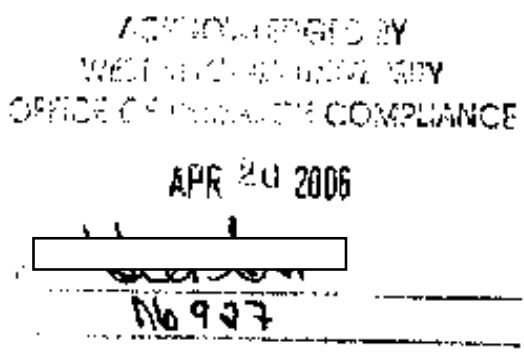

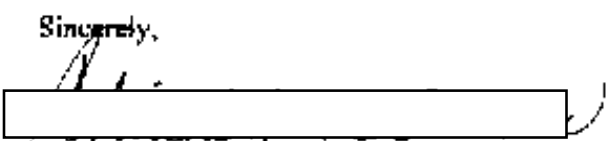

(Chyisthe' Miric Walker, B.S. Grackuble SI udent

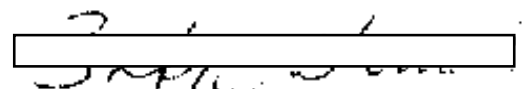

Bobbie Gibsof Warah, Ed.D

Dirctor. WVIU Nursery Sehool

Professe of Cthild Jkevelopment \&

Family Studes

Divlaloh of Fenlly and Coneumer Scle nant

Phot; 304 -2019400

Fax: 304-291-275
702 Ater t.lHe

Fo Eom 6124

Morgariown, WN 205006-6 ta 
APPENDIX D

\section{PERMISSION LETTERS}


Dewig College of Agnchlture, Forestry and Consumer Sclerwes

April 12, 2006

WWII IRH Hoard

Chrische Waker has pentission to conduer her stwy far her thesis at the Wut Nurrery sothul.

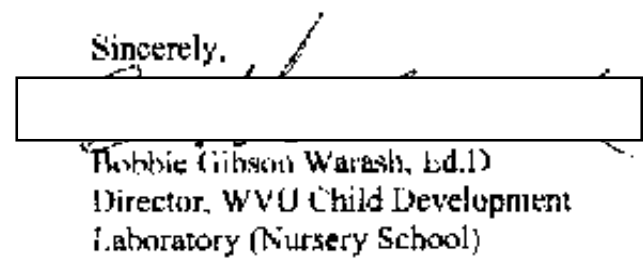

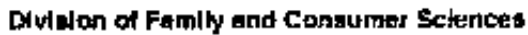

TO2 Milen Hal:

PG Asx 124

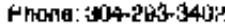

Muryenkank, WW $28509 \cdot 6124$

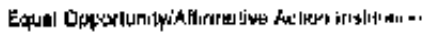




\section{Pierpont $C$ in Preschool

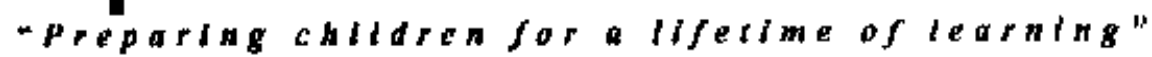 \\ 52 Harnor un Morgonlown, WV 426508

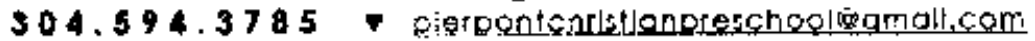

April 17, 2006

West Virginie Universily

Institutiona] Review Bond

Morgantown, WV 26506

Dear WVU IRB Board and/or To Whom II May Conceri:

This letter authorizeng gradunte student, Chrische Walker, to utilize Pierpont Christian Preschool in arder to conduet he sludy lon her thosis. We are glad to be of assistance.

If yuu have any questionts please fees free to contect me.

Sincerely.

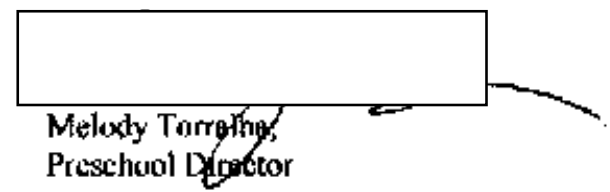




\section{APPENDIX E \\ REQUEST AND APPROVAL LETTER FOR \\ USING THE \\ CHILD BEHAVIOR SCALE \\ (CBS)}


Date: 'Thu, 14 Urt 201)4 17:27:17-0400 (EDT)

Frami "Chrleche' Mare Walker" scwalkemạmix.widu.edus Block Address

Tij. Gary.Ladd Q

stbject: Chlld Behavior Scale

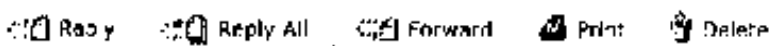

Hello,

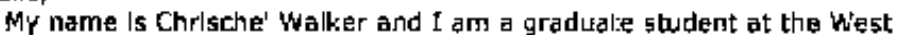

Virgina University, I am obtalnlng my master's I science in child develupment 8 farrl/y studies. J am starting on my thes/s for the

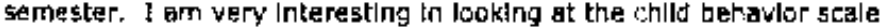
that was drawn from your research on a teacher-paport messure of the woung children's aggressive, withdrawn, and prosc clal behavlors. I

found to to be very interesting. I was workering vilhere I carn lind lite

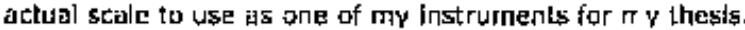

Thanks,

Chrische' M. Walker

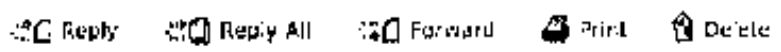

F-mall - Adtress Honk - hothons - Frit - Help

Hrivacy - Ierms nif Gery|re - shenritt - Top

(C) proplint

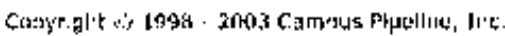


[ata: Tue, 20 0et 2004 11:08:3B -0700 "MST;

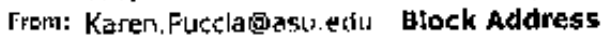

Situfect: Cag

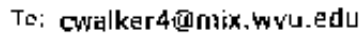

ci: grry.lindug̣jsu, ad

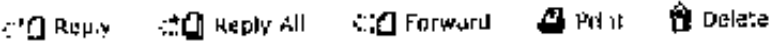

Denr chrribche'

Please fint the Child Behavior Scale attachęd tu blals emall. Thark you for

rour interest lin the ch5, and good luck with your thesis

Sincerely.

tharen

Karen B. Pucda

Gradiate Studen:

Famlly and Human Development

Mrlzona State Uniwersity

1711 5. Rural Road

Tempe, AZ 0524;

Phond: 480-565-3917

\begin{tabular}{|c|c|}
\hline 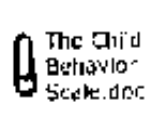 & 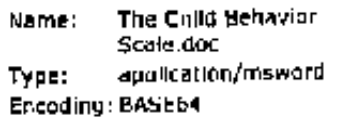 \\
\hline
\end{tabular}

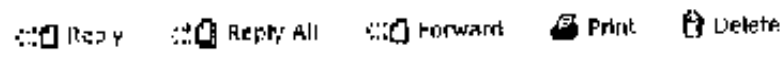

r-mal - Address Eogk - Optuns - Exht - Haip

Hrivacy - TerTs of Eer ylue - 5upport - Tap

(C) pipeline

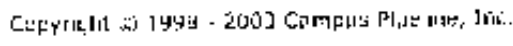

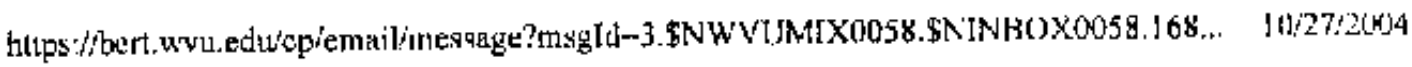


APPENDIX F

\section{CHILD BEHAVIOR SCALE}

(CBS) 
Rated by (teacher)!

School

\section{Chitd Bahavior Sgalo}

Pleate conster tha deschption contathed In each of the following hems below ard rate the extent to whlch anch of these descriptions applies to this thild, particularly in the contexl of his or the bethavior mith peers. For axemple, Circte 3-Cetaines andies" if the child often displays the behavior described $n$ the Etatement, circte 2-"Applies

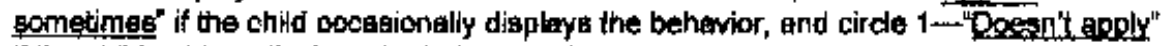
if the child beltom displays the behavior. Please circle onlw one responses per item.

\begin{tabular}{|c|c|c|c|c|c|c|}
\hline \multicolumn{6}{|c|}{2 I Applies gcmetimas } & $3=$ Certainy appllas \\
\hline 1 & 2 & 3 & $\begin{array}{l}\text { 1. Resilase. Runb about or jumps } \\
\text { up and down. Doasn't keep stll }\end{array}$ & $\begin{array}{ll}1 & 2 \\
1 & 2\end{array}$ & 3 & $\begin{array}{l}\text { 13. Fusey or overpertioular } \\
\text { 14. Tellig llas. }\end{array}$ \\
\hline 1 & 2 & 3 & 2. 8 quirmy, fugety onild. & 12 & 3 & 15. Has apeech difficulty. \\
\hline 1 & 2 & 3 & $\begin{array}{l}\text { 3. Desioya awn ar others' } \\
\text { praperty. }\end{array}$ & 12 & 3 & 16. Bulfer gther childrent. \\
\hline 1 & 2 & 3 & 4. Fights with ollher children. & 12 & 3 & 17. Inatteritive. \\
\hline 1 & 2 & 3 & $\begin{array}{l}\text { 6. Not much liked by other } \\
\text { children. }\end{array}$ & 12 & 3 & 18. Doesn't share toys. \\
\hline 1 & 2 & 3 & $\begin{array}{l}\text { 6. les worried. Worries aboul } \\
\text { ment things. }\end{array}$ & 12 & 3 & 19. Crims oatily. \\
\hline 1 & 2 & 3 & $\begin{array}{l}\text { 7. Irthabla; quick to "fly of the } \\
\text { handlo." }\end{array}$ & 17 & 3 & 70. Blames others. \\
\hline 1 & 2 & 3 & $\begin{array}{l}\text { 8. Appears migermble, unhappy; } \\
\text { teartul or distregaed. }\end{array}$ & 12 & 3 & 21. Gives up easily. \\
\hline 1 & 2 & 3 & $\begin{array}{l}\text { 9. Hess twithes, minnineristhe, } \\
\text { or tice of the tace and body }\end{array}$ & 12 & 3 & $x$ Inconglderate of others. \\
\hline 1 & 2 & 3 & 10. Is disobedient. & 12 & 3 & $\begin{array}{l}\text { 23. Kicks, bites or hits other } \\
\text { children. }\end{array}$ \\
\hline 1 & 2 & 3 & $\begin{array}{l}\text { 11. Has poor conoontration or } \\
\text { short attention span. }\end{array}$ & 12 & 3 & 24. Stares into space. \\
\hline 1 & 2 & 3 & $\begin{array}{l}\text { 12. Tends to be feartul or afraid } \\
\text { of new thinge or now } \\
\text { situations. }\end{array}$ & $\begin{array}{l}12 \\
12\end{array}$ & $\begin{array}{l}3 \\
3\end{array}$ & $\begin{array}{l}\text { 26. Prators to play alone. } \\
\text { 26. Helps other chibiren. }\end{array}$ \\
\hline
\end{tabular}




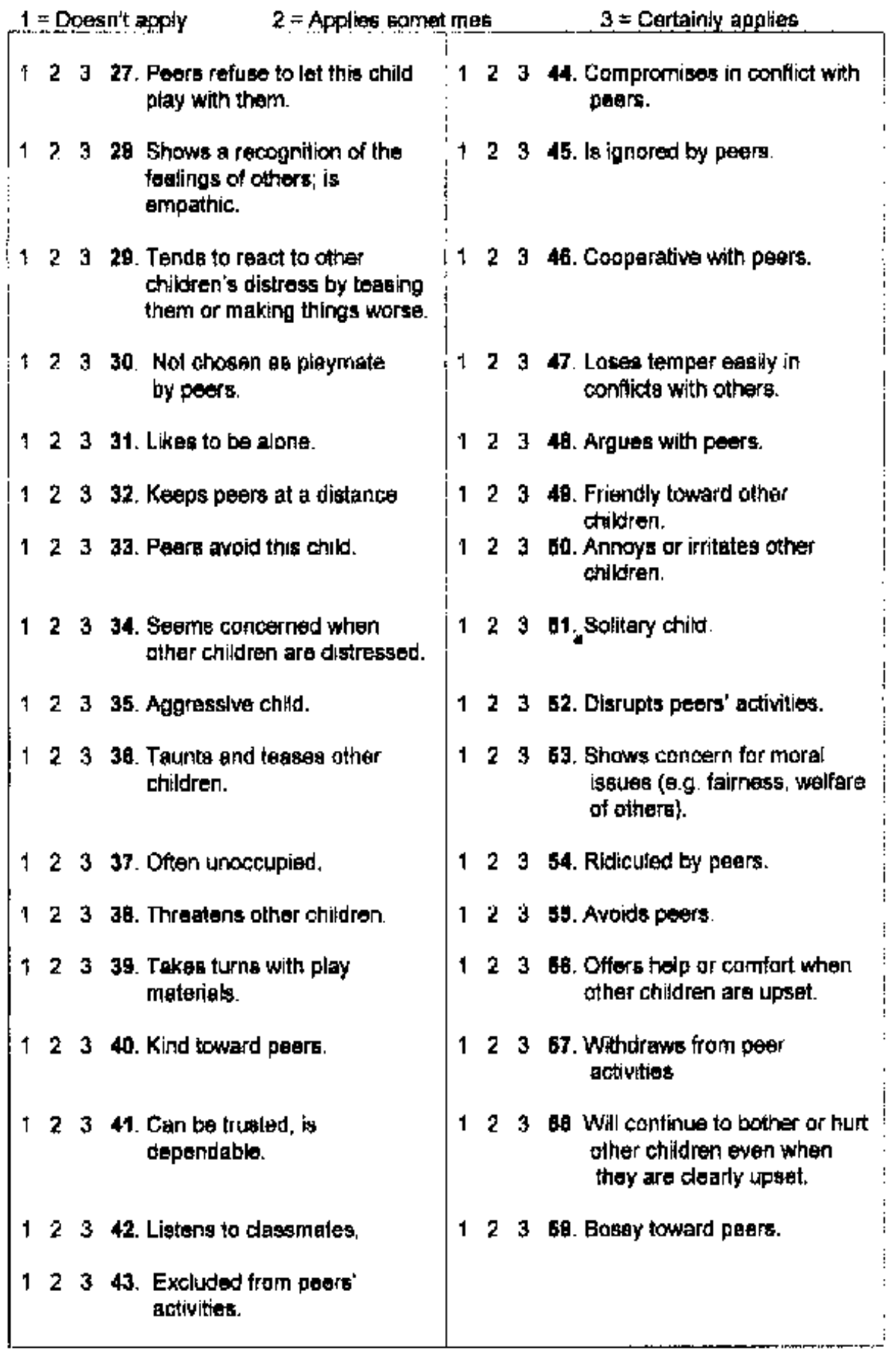


APPENDIX G

\section{BEHAVIORAL ACADEMIC SELF-ESTEEM SCALE}

(BASE) 


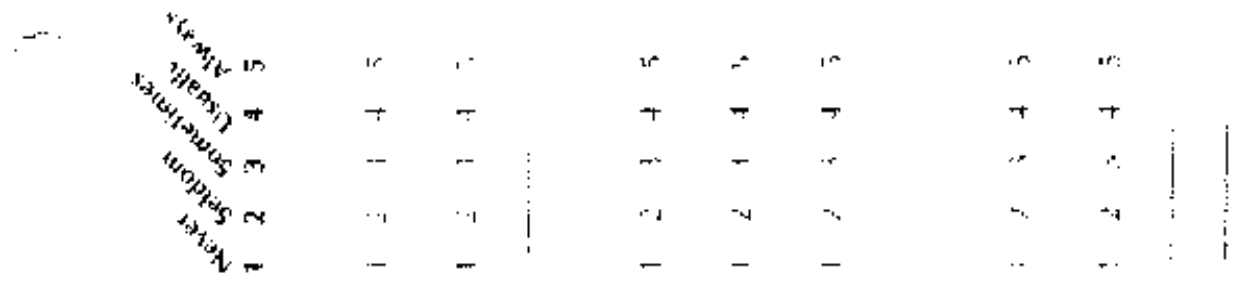
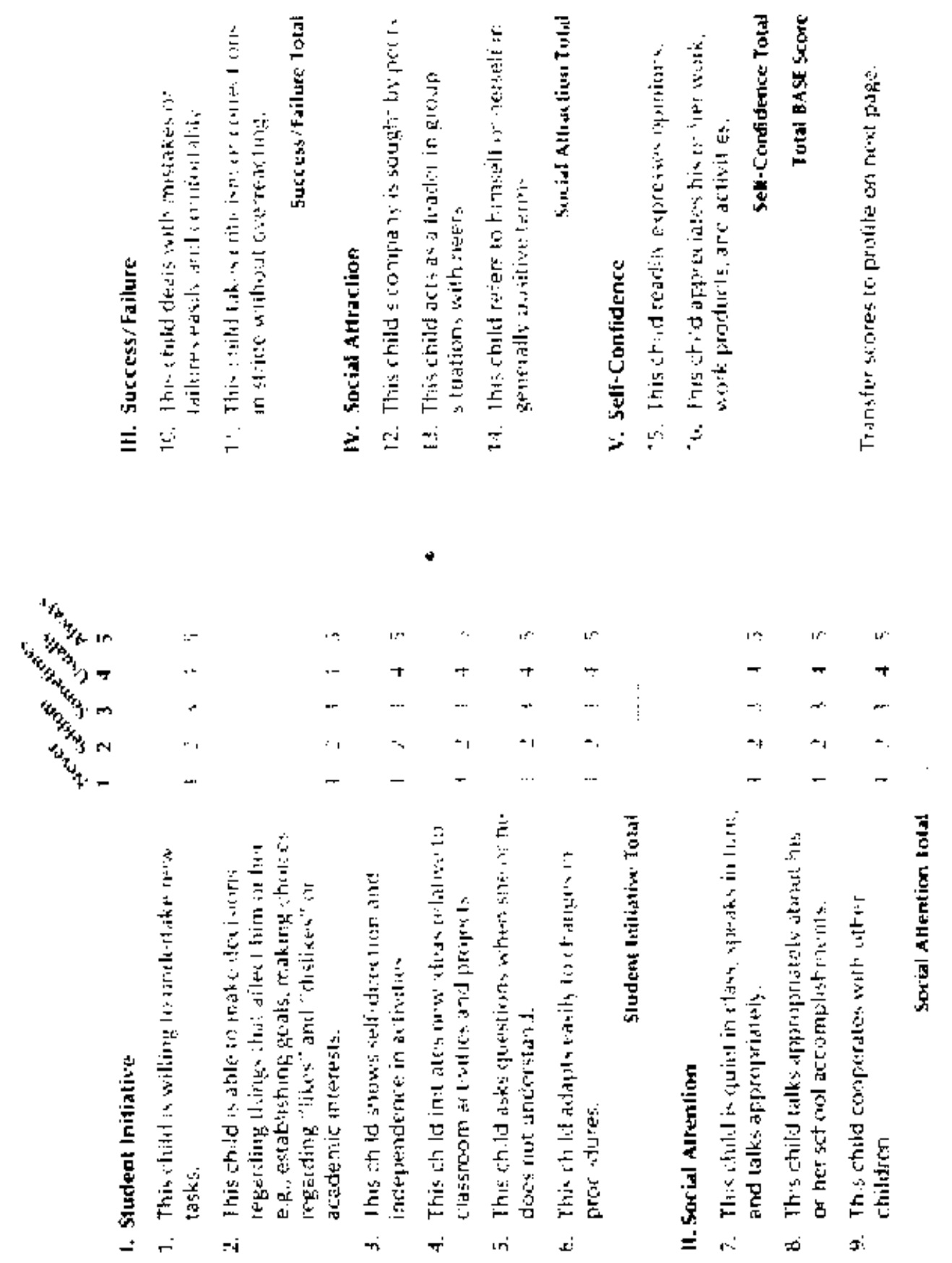
VITA

Chrische’ Marie Walker

Personal Date

Name:

Chrische’ Marie Walker

Date of Birth:

November 6, 1981

Place of Birth:

Institute, WV

Education

West Virginia University

Morgantown, West Virginia

Master of Science in Human Resources \& Education (2006)

West Virginia University

Morgantown, West Virginia

Bachelor of Science in Family and Consumer Sciences

(2004)

Work Experience

Charleston Community Day Care Center

Charleston, West Virginia

Assistant Director

Summer 2006

Lighthouse Child Care \& Development Center

Charleston, West Virginia

Lead Teacher

Summer 2005

West Virginia Public Day Care Center

Charleston, West Virginia

Assistant Teacher

Summer 2004

The Shoe Department

Charleston, West Virginia / Morgantown, WV

Sales Associate / Assistant Manager

August 1999 - May 2006

Professional Organizations and Honoraries

National Association for the Education of Young Children

Alpha Kappa Alpha Sorority, Inc.

Dean’s List 